\title{
Reforma de la negociación colectiva en España y sistema de Relaciones Laborales
}

\author{
María Emilia CASAS BAAMONDE \\ Catedrática de Derecho del Trabajo y de la Seguridad Social \\ Universidad Complutense de Madrid \\ mariaemiliacasas@pdi.ucm.es
}

Recibido: 24-03-2013

Aceptado: 21-05-2014

\begin{abstract}
RESUMEN
El artículo analiza las recientes reformas del marco legal de la negociación colectiva de eficacia general, negociación colectiva típica del ordenamiento español, introducidas en los años 2010 a 2014 coincidiendo con la gran crisis económico-financiera desencadenada en 2008 y las crisis político-monetaria europea y político-económica española. El conjunto reformador, y especialmente las reformas legislativas últimas de 2012-2014, han tenido una especial incidencia cualitativa en el sistema negocial, marcando el cambio de orientación de su regulación desde el derecho constitucional a la negociación colectiva y a la fuerza vinculante de los convenios, estrechamente conectado con el de libertad sindical, al derecho constitucional a la libertad de empresa y el deber constitucional de los poderes públicos de velar por la defensa de la productividad. Las reformas legislativas de 2012 se han dirigido a procurar que la negociación colectiva sea un instrumento, y no un obstáculo, para adaptar las condiciones laborales a las concretas circunstancias de la empresa. Para ello han postergado la función normativa tradicional del convenio colectivo de compensar la desigualdad fundamental de las relaciones de trabajo mediante la limitación de la autonomía individual y el poder de decisión empresarial y acentuado la función de gestión del convenio colectivo a través de diferentes técnicas convergentes en su resultado: la prioridad aplicativa del convenio colectivo de empresa como regla imperativa para la negociación colectiva de ámbito superior, la modificación e inaplicación singular a la empresa de los convenios colectivos aplicables mediante arbitraje público obligatorio, la modificación ante tempus del convenio colectivo, y la limitación temporal de la eficacia ultraactiva de los convenios colectivos en los procesos de renovación convencional. Para el logro de sus objetivos reformadores, y no obstante alguna excepción en materia no menor (la ultraactividad de los convenios colectivos) en que dichos objetivos se alcanzan mediante la cesión por la ley de espacio a la negociación colectiva, la ley laboral flexibilizadora se hace autosuficiente y rígida. Dichas reformas proyectan sus efectos sobre el sistema de relaciones laborales en su conjunto, trazando líneas de transformación de innegable trascendencia jurídica, entre las que destaca con particular nitidez la promoción, recurriendo a técnicas imperativas, de la negociación colectiva de empresa, que, más allá de su incidencia en la estructura de la negociación colectiva, se ofrece como garantía de mayor flexibilidad y competividad empresarial, afecta a las funciones del derecho a la negociación colectiva, encauza un principio de diferenciación que los viejos intentos de individualizar las condiciones de trabajo no consiguieron, y desplaza los poderes de las confederaciones sindicales y empresariales hacia las representaciones de empresa y los empresarios.
\end{abstract}

Palabras clave: negociación colectiva, reformas, constitución, libertad de empresa, flexibilidad, sindicatos, convenios de empresa, arbitraje publico obligatorio, ultraactividad

\section{Reform of Collective Bargaining in Spain and Industrial Relations System}




\begin{abstract}
The article discusses the recent reforms of the collective bargaining's legal framework of general efficiency, collective bargaining representative of the Spanish legal system, introduced in the years 2010 to 2014, coinciding with the global economic and financial crisis, which began in 2008, the European political and monetary crisis and the and political-economic crisis en Spain. The reforms, and especially the recent legal reforms of 2012-2014, have had a qualitative impact on the bargaining system, shifting the regulation's orientation from the constitutional right to collective bargaining, and to the binding force of conventions, closely connected with the freedom of association, to the constitutional right to free enterprise and constitutional duty of the authorities to ensure the safeguarding of productivity. The legislative reforms of 2012 aimed at ensuring that collective bargaining is a tool, not an obstacle, to adapt working conditions to the specific circumstances of the company. For it they have postponed the traditional role of the collective agreement to compensate the fundamental inequality of labor relations by limiting individual autonomy and the power of corporate decision, as well as emphasizing the management function of the collective agreement through different techniques with convergent results: applicative priority of the company's collective agreement as a mandatory rule for higher-level collective bargaining, modification and unique company inapplicability of the collective agreement through binding arbitration public, ante tempus modification of the collective agreement, and the temporal limitation of the ultraactive effectiveness of collective agreements within agreement renewal processes. To achieve its reformation goals, and yet there is some exception in a non-minor matter (ultra-activity of collective agreements) in which reformation goals are achieved through the transfert of competencies by the law to the collective bargaining, labor law flexibilization tends to self-sufficiency and rigidness. These reforms project their effects on labor relations system as a whole, drawing lines of transformation of undeniable legal significance, among which stands the promotion, using imperative techniques, of collective bargaining at company level, which, beyond their impact on the structure of collective bargaining, is offered as a guarantee of the higher flexibility and corporate competitiveness, affects the functions of the right to collective bargaining channeled a principle of differentiation that old attempts to individualize working conditions failed, and displaces the powers of trade unions and business confederations to representations of companies and businessmen.
\end{abstract}

Keywords: collective bargaining, legislative reforms, constitution, free enterprise, flexibility, trade unions, public binding arbitration, ultraactive effectiveness

\title{
REFERENCIA NORMALIZADA
}

Casas Baamonde, M. E. (2014). "Reforma de la negociación colectiva en España y sistema de relaciones laborales", Cuadernos de Relaciones Laborales, Vol. 32, núm. 2, p. 275-309.

SUMARIO: Introducción: Primeros efectos de las reformas legislativas recientes y líneas de evolución del sistema español de negociación colectiva. 1. Las reformas del marco legal de la negociación colectiva. 1.1. La crisis financiero-económica de 2008 y las reformas legales de los años 2010-2011 y de 2012. 1. 2. La continuación de la política de reformas "estructurales" del marco legal de la negociación colectiva en 2012, 2013 y 2014. 2. El marco constitucional del derecho a la negociación colectiva. 21 . El derecho a la negociación colectiva en la Constitución Española. 2. 2. El cambio del modelo legal de negociación colectiva de eficacia general: del derecho a la negociación colectiva al derecho a la libertad de empresa y la defensa de la productividad. 2. 3. Las técnicas jurídicas reformadoras de la negociación colectiva como instrumento de adaptación de las condiciones de trabajo a las necesidades empresariales. 2.3.1. La prioridad aplicativa del convenio colectivo de empresa, indisponible por acuerdos interprofesionales y acuerdos y convenios colectivos sectoriales, estatales y autonómicos, sobre estructura de la negociación colectiva. 2.3.2. La inaplicación singular a la empresa y la modificación de los convenios colectivos aplicables mediante arbitraje público obligatorio. 2.3.3. La limitación temporal de la eficacia ultraactiva de los convenios colectivos. 2.3.4. La rigidez de la ley flexibilizadora. 3. Conclusiones: las transformaciones del sistema de relaciones laborales. Un nuevo modelo de comportamiento de los actores. 4. Bibliografía. 


\section{Introducción: Primeros efectos de las reformas legislativas recientes y líneas de evolución del sistema español de negociación colectiva}

Con mayor perspectiva temporal se analizará el alcance jurídico (con su interpretación jurisprudencial) y la influencia real sobre el sistema de relaciones laborales de las importantes reformas del marco legal de la negociación colectiva de eficacia general habidas en España en los años 2010-2012, prolongadas en 2013 y 2014 en aspectos derivados que prosiguen el sentido de las reformas legales de 2012. Mientras, cabe exponer esas reformas legales y perseguir su pulso en los cambios inmediatos producidos en el comportamiento de la negociación colectiva, que prefiguran líneas de transformación estructural del derecho a la negociación colectiva, de su alcance y de sus funciones, de la posición de los sujetos negociadores, de los sindicatos y de las asociaciones empresariales, y del sistema de relaciones laborales en su conjunto. No conviene olvidar que la Ley reformadora $3 / 2012$ advirtió en su preámbulo que contenía "medidas incisivas y de aplicación inmediata, al objeto de establecer un marco claro que contribuya a la gestión eficaz de las relaciones laborales y que facilite la creación de puestos de trabajo, así como la estabilidad en el empleo que necesita nuestro país" (II).

Son ya numerosos los estudios doctrinales sobre los primeros efectos materiales de las reformas del marco legal de la negociación colectiva de eficacia general en la propia negociación colectiva (por todos, J. CRUZ, 2013, págs. 199 a 214). Por su parte, el denominado "Informe de evaluación del impacto de la reforma laboral", de agosto de 2013, del Ministerio de Empleo y Seguridad Social proporcionó información significativa, aunque provisional y parcial y discutible y discutida, sobre ese impacto inicial de la reforma en el sistema de negociación colectiva y sus consecuencias económicas y sociales: el intenso proceso de moderación y reducción salarial, que ha actuado como mecanismo de devaluación interna, para la recuperación de la competitividad empresarial, del sector exterior señaladamente, y a través de ella de un empleo que no llega -las ganancias de productividad y competitividad no se han destinado a la inversión y a la creación de empleo, a costa del agravamiento de la caída del consumo interno, del endeudamiento privado, de la desigualdad y de la pobreza, y de la difícil financiación del sistema de Seguridad Social. El incremento de los procedimientos de inaplicación de convenios colectivos a las empresas o "descuelgues", junto con el favorecimiento de los convenios colectivos de empresa, ha tenido esos efectos reductivos de los salarios y ampliatorios de las jornadas. La generalización normalizada de la institución de la "doble escala salarial" y el retraimiento significativo de la negociación colectiva, de su tasa de cobertura, han sido otras consecuencias derivadas de la pérdida de ultraactividad de los convenios colectivos como nueva solución legal al bloqueo de las negociaciones. La acción conjugada de las técnicas reformadoras del marco legal de la negociación colectiva ha contribuido, en suma, a posibilitar el proceso de ajuste de las rentas salariales a la devastadora crisis financiero-económica y de erosión de las condiciones de trabajo por vía de la erosión de la fortaleza de la 
negociación colectiva, especialmente de la negociación colectiva sectorial, pero sin ganancias para el empleo -¿todavía?-, objetivo formal último de las reformas legales.

Las primeras valoraciones de CEOE ("Valoración de la reforma laboral y las propuestas de mejora"). Asamblea general de CEOE, 18 de junio de 2013), UGT ("Más de un año de reforma laboral: evolución del empleo, la contratación, los despidos y la negociación colectiva"), Gabinete técnico confederal, 31 de julio de 2013; y "Mas de un año de reforma laboral: notas al Informe de Impacto del MEISS", 6 de agosto de 2013) y CCOO ("Efectos de la reforma laboral 2012". Comisión ejecutiva confederal, septiembre de 2013) abundaron en el efecto de las reformas legales de la negociación colectiva de contribución a la devaluación salarial. La valoración positiva de CEOE destacó la moderación salarial pactada en los "nuevos" convenios colectivos de empresa firmados en 2012 y la adaptación de la negociación colectiva a las necesidades de flexibilidad y competitividad de las empresas, a lo que sumó la propuesta de suprimir la técnica legal de la eficacia ultraactiva del convenio denunciado y vencido "como herramienta para la imprescindible renovación de los convenios en aras a la competitividad de las empresas y la estabilidad en el empleo de los trabajadores (pág. 12). En sus evaluaciones respectivas, los sindicatos mas representativos confirmaron "la importante reducción del incremento salarial pactado en los convenios" en 2013 y la pérdida de poder adquisitivo de los trabajadores desde 2009 (CCOO, págs. 4 y 9), resultante de los nuevos convenios colectivos de empresa y de grupo de empresas y de los acuerdos y decisiones - mas acuerdos que decisiones de inaplicación a las empresas de convenios colectivos sectoriales, así como de la limitación legal de la ultraactividad de los convenios colectivos, contestando esa pérdida de capacidad adquisitiva de los trabajadores por no haber sido compensada con "el mantenimiento e incremento de puestos de trabajo, lo que a su vez está impidiendo el consumo de las familias, afectando negativamente a la demanda interna y en consecuencia a los niveles de empleo" (UGT, pág. 10; CCOO, págs. 7 y 29).

El Real Decreto-ley 16/2013, de 20 de diciembre, de medidas para favorecer la contratación estable y mejorar la empleabilidad de los trabajadores, volvió a atribuir a la "reforma laboral" de 2012 los beneficiosos efectos de haber contribuido a dinamizar "la negociación colectiva en un marco más equilibrado de relaciones laborales", "frenar el ritmo de destrucción de empleo, ahorrando miles de despidos, y a la moderación salarial que ha dado lugar a una recuperación de la competitividad esencial de nuestra economía" (exposición de motivos, I).

Los primeros efectos materiales de las últimas reformas legislativas sobre la negociación colectiva de eficacia general no dejan, pues, lugar a dudas. Hay coincidencia en señalar que esas reformas han producido el resultado de reducir progresivamente los salarios y el poder adquisitivo de los trabajadores (en torno al 10 por 100 de las rentas salariales, al 15 por 100 en el empleo público, en los últimos cinco años), al que ha acompañado la reducción apreciable del número de trabajadores incluidos en los convenios colectivos vigentes (J. Cruz, 2013, págs. 199 y 206). La debilidad de la actividad convencional se prueba por su papel en la fijación de los salarios, según el balance del Ministerio de Empleo y Seguridad 
Social, que constata efectivamente la atonía (Estadística de convenios colectivos de trabajo, avance 2012); Comisión Consultiva Nacional de Convenios Colectivos, Observatorio de la negociación colectiva, Boletín núm. 42, enero-febrero 2014, pág. 3).

Situando esas reformas legales en un contexto mas general, es aún delicado establecer la determinación del alcance real de las distintas decisiones reformadoras sobre las bases estructuradoras de nuestro sistema negocial colectivo y de nuestro sistema de relaciones laborales. Entre otras razones, por la obvia de que la propia negociación colectiva se encargará de fijar ese alcance. Con todo, el momento es propicio para efectuar una reflexión general sobre las transformaciones de la regulación legal de la negociación colectiva y su incidencia en el conjunto del sistema de relaciones laborales en una perspectiva de apreciación cualitativa. Intentaré, en las páginas que siguen, ofrecer una visión de conjunto en la que sea posible aislar las tendencias esenciales de las evoluciones en curso en sus distintas dimensiones. Para ello será preciso exponer previamente el sentido y las técnicas de las últimas reformas legales de la negociación colectiva de eficacia general, advirtiendo de antemano que no se trata de reformas coyunturales, como tampoco lo son las líneas de tendencia que enmarcan y desarrollan. Tampoco son irreversibles. Obviamente, han sido objeto de apreciaciones diversas.

\section{Las reformas del marco legal de la negociación colectiva}

No será exagerado señalar que, por su relevancia en el cambio de orientación que significan, las modificaciones incorporadas por las reformas legislativas del régimen jurídico de la negociación colectiva de eficacia general o "estatutaria" de 2010-2012 han marcado el final de una época, la iniciada por el primer Estatuto de los Trabajadores de 1980 en desarrollo de la Constitución de 1978 y continuada por el Estatuto de los Trabajadores refundido en 1995, y el inicio de otra, aunque dentro del modelo de negociación colectiva inicial configurado por aquella primera ley laboral democrática: un modelo de negociación colectiva regulado por la ley en los sujetos negociadores para asegurar su representatividad, en el procedimiento negociador y en parte del contenido de los convenios colectivos, cuya fuerza vinculante se basó en su eficacia personal general y en su valor normativo como fuente del derecho.

Esta construcción legislativa del derecho a la negociación colectiva y a la fuerza vinculante de los convenios garantizados por el artículo 37.1 de la Constitución Española y la lectura que de ella hizo la jurisprudencia, empezando por la jurisprudencia constitucional, se habían mostrado, a lo largo de su proceso de asentamiento y consolidación durante mas de treinta años, especialmente estables y resistentes a los cambios: ni las reformas legislativas de esta parte del Estatuto de los Trabajadores (en adelante, ET) habían seguido el ritmo de las que, a lo largo de aquellas décadas, actuaron sobre su título I (sin perjuicio de la proyección de la regulación del contrato de trabajo por el título I del ET sobre la negociación colectiva), ni, en consecuencia, la jurisprudencia registró bruscos movimientos. Los 
cambios normativos y de funcionamiento del sistema de negociación colectiva de eficacia general resultaron de la trasferencia por la ley de la regulación de nuevas materias al espacio propio de la negociación colectiva, potenciando así su condición de "elemento regulador de las relaciones laborales" y la "mejora de sus contenidos", sin dejar de reconocer, ya en la década de los 90 del pasado siglo, la de "instrumento fundamental para la deseable adaptabilidad por su capacidad de acercamiento a las diversas y cambiantes situaciones de los sectores de actividad y de las empresas" (operación llevada a cabo por la Ley reformadora 11/1994, de 19 de mayo). Las transformaciones del sistema negocial resultaron también de nuevas prácticas de negociación colectiva desarrolladas por los representantes de los trabajadores y los empresarios y sus representantes, y del acogimiento o corrección por la jurisprudencia de esas innovaciones de los interlocutores sociales complementando las reglas del marco legal.

\subsection{La crisis financiero-económica de 2008 y las reformas legales de los años 2010-2011 y de 2012}

Las dos etapas de las reformas españolas últimas han reposado sobre el Real Decreto-ley 10/2010, de 16 de junio, de medidas urgentes para la reforma del mercado de trabajo, sustituido, tras su tramitación parlamentaria por el procedimiento de urgencia, por la Ley 35/2010, de 17 de septiembre, de igual título, y el Real Decreto-ley 7/2011, de 10 de junio, de medidas urgentes para la reforma de la negociación colectiva; y, después ya del cambio político de 2011, sobre el Real Decreto-ley 3/2012, de 10 de febrero, de medidas urgentes para la reforma del mercado laboral, convertido también en Ley 3/2012, de 6 de julio, de igual denominación. Mas extensa la reforma específica de la negociación colectiva de 2011 de preceptos, "principalmente", del título III del ET, los cambios normativos de 2012 han tenido, sin embargo, como se reconoce generalmente, una incidencia cualitativa de mayor intensidad sobre el sistema negocial español.

Las razones de estos cambios se explican por las propias normas reformadoras. Según el Real Decreto-ley 7/2011, el sistema de negociación colectiva había ido acumulando a lo largo del tiempo "disfunciones" que le restaban "eficiencia y, particularmente, capacidad de adaptación a las condiciones cambiantes de la economía y del empleo y del propio modelo de relaciones laborales", señaladamente ante "la situación actual de la economía, del empleo y del desempleo" (exposición de motivos, II y III). Para su corrección operó sobre la estructura de la negociación colectiva y la concurrencia de convenios colectivos, estableciendo, supletoriamente, la prioridad aplicativa del convenio de empresa $-\mathrm{y}$ de los convenios de grupo y de empresas en red- sobre el convenio de ámbito sectorial en relación con determinadas materias "más cercanas a la realidad de las empresas" para su "mejor acomodación [...] al entorno económico y productivo en que se desenvuelven" (reformas de los arts. 83.2 y 84 ET). Actuó sobre los contenidos y vigencia de los convenios colectivos para fomentar su contribución a la flexibilidad interna y agilizar los procesos de negociación y renovación con el fin de aumentar la "capacidad de adaptabilidad" de aquéllos "a los cambios en la 
situación económica y sociolaboral en unos términos que equilibren flexibilidad para las empresas y seguridad para los trabajadores" bien que manteniendo como regla última, también aquí con valor supletorio, la ultraactividad indefinida de los convenios colectivos (reformas de los arts. 85.3, 86.3 y 89.1 y 2 ET). Siguiendo las reformas de 2010, bajo la rúbrica "flexibilidad interna negociada", facilitó la modificación de los convenios colectivos de eficacia general -con ciertas limitaciones para los convenios colectivos de sector- en una serie abierta de materias relativas, entre otras, a la jornada de trabajo, al horario y distribución del tiempo de trabajo, al régimen de trabajo a turnos, a los sistemas de trabajo, rendimiento y remuneración, y a las funciones, por causas económicas, técnicas, organizativas y de producción, y la inaplicación acordada del régimen salarial de los de ámbito superior a la empresa por causas económicas, que redefinió (reformas de los arts. 41.6 y 82.3 ET). Introdujo nuevas reglas de legitimación de los sujetos negociadores con el fin de adaptarlas a las "nuevas realidades empresariales" y "para favorecer la flexibilidad interna negociada con los representantes de los trabajadores" (reformas de los arts. 87 y 88 ET; y fuera de su título III, de los arts. $40.2,41.4,51.2 \mathrm{ET})$. Y favoreció la solución autónoma o extrajudicial de los conflictos durante la negociación, especialmente el arbitraje obligatorio, impuesto con tal carácter en defecto de pacto en los acuerdos interprofesionales reguladores de los procedimientos arbitrales, y en la modificación, inaplicación salarial y aplicación de los convenios y de las medidas de flexibilidad interna (reformas de los arts. 85.3, 82.3, 91 y 41.6 ET y disposición adicional primera, apartado 2).

Las reformas de 2012, que partieron mas radicalmente de "la insostenibilidad del modelo laboral español" evidenciada por la crisis económica (a esa insostenibilidad se había referido ya la Ley 35/2010 en su preámbulo, I), respondieron "al objetivo de procurar que la negociación colectiva sea un instrumento, y no un obstáculo, para adaptar las condiciones laborales a las concretas circunstancias de la empresa" (Ley 3/2012, preámbulo, I y IV). Centraron sus efectos primeros sobre la modificación e inaplicación de los convenios colectivos (arts. 41.6, 82.3 y 85.3 ET), la atribución de prioridad aplicativa al convenio colectivo de empresa concurrente frente al sectorial vigente (art. 84.1 y 2 ET), y la eficacia temporal y limitación del período de ultraactividad de los convenios colectivos denunciados y vencidos (arts. 86.1 y $3,89.2$ y 90.3 ET) para permitir "la adaptación de los salarios y otras condiciones de trabajo a la productividad y competitividad empresarial".

Las reformas de 2012 volvieron sobre estas tres cuestiones nucleares que ya habían sido objeto de las reformas de 2010 y 2011, "bienintencionadas y orientadas en la buena dirección", pero "fallidas" según la Ley 3/2012 (preámbulo, I), que de este modo había constituido el preludio de la nueva orientación legal, si bien las nuevas reformas legales pronunciaron decisivamente el sentido de las precedentes mediante, de un lado, su ampliación y, de otro, su virtual expulsión del ámbito de la autonomía colectiva y su inserción en el de la regulación legal, que prescindió de los acuerdos de los titulares del derecho constitucional a la negociación colectiva para producir los resultados queridos: sometimiento a arbitraje público obligatorio, en último término, de los conflictos producidos en los procesos de modificación e 
inaplicación a la empresa de los convenios colectivos o descuelgues (reconducidos aquéllos a éstos), también de los propios convenios de empresa (sin descuelgue entonces, o con "autodescuelgue" en otro caso), respecto de un mayor número de condiciones de trabajo (de modificación posible asimismo en los convenios colectivos de sector) y a cuyas causas económicas se añadieron las técnicas, organizativas y productivas; descentralización de la estructura de la negociación colectiva a la empresa al margen de los convenios y acuerdos colectivos estatales o autonómicos a los que expresamente se prohíbe disponer de la prioridad aplicativa del convenio colectivo de empresa; y evitación de la "petrificación" de las condiciones de trabajo pactadas en convenios colectivos vencidos mediante la limitación de su eficacia ultraactiva finalmente a un año (por la Ley 3/2012), aquí sí, expresamente, salvo pacto en contrario.

Además, las reformas de 2012 se separaron de la de 2011 en la supresión de la imposición por la ley de plazos máximos a los procesos de negociación (salvo el de un mes en la constitución de la comisión negociadora desde la denuncia del convenio colectivo: art. 89.2 ET) y de obligaciones de negociar materias concretas de las que resultan acuerdos incorporados al contenido mínimo necesario de los convenios colectivos estatutarios -sobre los plazos máximos de negociación de nuevos convenios o sobre medidas de flexibilidad interna- que en la citada reforma de 2011 se habían multiplicado para dinamizar y agilizar los procesos de renovación negocial y facilitar la flexibilidad interna negociada. En este punto, las reformas de 2012 decidieron también sustituir la flexibilidad interna negociada por la flexibilidad interna decidida unilateralmente por el empresario, facultado por la ley, al amparo de la libertad de empresa. En lo demás, las reformas de 2012 integraron las precedentes de 2011 (de los arts. 83.2, 84.3 y 4, 87, 88, 89.1 y 91 ET), estableciendo, en parte, una suerte de continuidad del régimen jurídico de la negociación colectiva que, a su vez, la reforma de 2011 había establecido, no ya con la Ley $35 / 2010$ de la que fue su complemento, sino con el régimen legal precedente de 1995, y éste con el de 1980.

Continuidad y discontinuidad caracterizaron, pues, la sucesión normativa reformadora del marco legal de la negociación colectiva del bienio 2011/2012. Nada debía ser como antes a tenor del cambio político y de los graves problemas del mercado de trabajo español, señaladamente la altísima tasa de desempleo, ligados, según la Ley 3/2012, a los "fundamentos mismos de nuestro modelo sociolaboral", pero las reformas de 2012 acogieron parte de las realizadas por el Gobierno anterior y modificaron otras con la "envergadura" que la situación y las instituciones económico-financieras mundiales y europeas (FMI, BCE y Comisión Europea) reclamaban (preámbulo, I, de la Ley reformadora 3/2012).

Esas reformas legales, como otras europeas de igual orientación, se produjeron en la encrucijada en la que la crisis financiero-económica mundial confluyó con la político-institucional de la Unión Europea, la monetaria de la "eurozona", y la particular crisis económica y política española, agudizada por el fin de la "burbuja" inmobiliaria, el incremento imparable del desempleo, la crisis bancaria, la acumulación creciente de la deuda soberana, la amenaza del rescate-país y, mas 
tarde, en junio de 2012, la solicitud por el Gobierno español a la Unión Europea del rescate bancario. Planeando la amenaza del rescate de la economía española, el Real Decreto-ley 7/2011 también había enlazado expresamente la urgencia de su aprobación con el cumplimiento de los compromisos adquiridos por el Gobierno español en el Consejo Europeo de primavera de 2011, añadiendo que ese "cumplimiento inmediato" debía servir para "seguir consolidando la confianza externa en la estabilidad y la solidez presente y futura de la economía española" (exposición de motivos, VI). El 27 de septiembre de 2011 se publicaría en el Boletín Oficial del Estado la Reforma del artículo 135 de la Constitución para dar valor constitucional al principio de estabilidad presupuestaria, realizada por el procedimiento de lectura única y de urgencia, con rapidez inusitada (ATC 9/2012), reforma constitucional demandada por Alemania y exigida después por el Tratado de Estabilidad, Coordinación y Gobernanza en la Unión Económica y Monetaria, firmado en Bruselas el 2 de marzo de 2012 por veinticinco Estados miembros de la Unión Europea (todos de los entonces veintisiete Estados miembros a excepción del Reino Unido y la República Checa).

En el plano interno, no es difícil discernir, incluso, la existencia de un cierto diálogo entre las normas legales reformadoras de 2011 y de 2012 a propósito de la adecuación constitucional de los mecanismos jurídicos, incitativos y resolutorios, respectivamente adoptados para lograr, en casos justificados por necesidades empresariales, la modificación e inaplicación parcial a la empresa de los convenios colectivos de eficacia general. El Real Decreto-ley 7/2011, que proclamó su pleno respeto de "los elementos esenciales de nuestro sistema de negociación colectiva" y, singularmente, de "la autonomía colectiva" reconocida en el art. 37.1 CE, dijo avanzar en proporcionar "mayor alcance y contenido" a los procedimientos no judiciales de solución de conflictos en línea con los modernos sistemas de relaciones laborales de nuestro entorno hasta donde era posible "respetando la autonomía colectiva" (exposición de motivos, IV y V). La Ley 3/2012, que consideró aquel avance insuficiente, optó, ante la falta de acuerdo y la no solución del conflicto por otras vías autónomas, por el sometimiento obligatorio del desacuerdo a petición de una sola de las partes a un arbitraje canalizado a través de la Comisión Consultiva Nacional de Convenios Colectivos u órganos tripartitos similares de las Comunidades Autónomas, cuya intervención justificó "en la necesidad de que los poderes públicos velen por la defensa de la productividad tal y como se deriva del artículo 38 de la Constitución Española”. Sin alusión alguna a la autonomía colectiva ni al derecho constitucional a la negociación colectiva reconocido en el art. 37.1 de la Constitución.

Ninguna de dichas reformas contó con el consenso social -como regla de reconocimiento- ni con el político de la fuerza mayoritaria de la oposición parlamentaria al Gobierno autor de las modificaciones legislativas. Precedidas las reformas de 2010 y de 2011 de un proceso de diálogo social, el Gobierno socialista se comprometió a ejercer su poder de iniciativa legislativa para la reforma de la negociación colectiva en los términos que acordasen los interlocutores sociales en ejercicio de su autonomía colectiva según lo por ellos pactado en el Acuerdo para el 
Empleo y la Negociación Colectiva, suscrito el 9 de febrero de 2010 por CEOE, CEPYME, CCOO y UGT (disposición adicional vigésima primera de la Ley 35/2010). Así, en el origen de la reforma de 2011 estuvo el fracaso de ese acuerdo bipartito sobre la reforma de la negociación colectiva cuyo compromiso de negociación había sido renovado en el Acuerdo de criterios básicos para la reforma de la negociación colectiva integrado en el Acuerdo Social y Económico para el crecimiento, el empleo y la garantía de las pensiones alcanzado el 2 de febrero de 2011. La reforma de 2012 trajo causa de la decisión del Gobierno del partido popular de llevar adelante la reforma legislativa del "mercado laboral" mediante una nueva intervención de urgencia para alcanzar los objetivos pretendidos de recuperación de la productividad y competitividad empresariales $\mathrm{y}$, en su consecuencia, del empleo a través de la flexibilización, con eficacia inmediata, de diferentes instituciones laborales, entre ellas y con valor principal, de la negociación colectiva. Intervención de urgencia que no contó con la consulta formal de los interlocutores sociales, y ello pese a venir inmediatamente precedida la aprobación del Real Decreto-ley 3/2012 del II Acuerdo para el Empleo y la Negociación Colectiva (II AENC) alcanzado por CEOE, CEPYME, CCOO y UGT el 25 de enero de 2012, de cuyos compromisos aquélla primera norma legal reformadora prescindió y desbordó (lo que merecería la crítica de la OIT por vulnerar los principios consagrados en sus Convenios núms. 87 y 98, sobre libertad sindical y negociación colectiva: $371^{\circ}$ Informe del Comité de Libertad Sindical, sesión del Consejo de Administración, Ginebra, 13-27 de marzo de 2014, parágrafos 317 465 , en respuesta a la queja de CCOO y UGT). Con todo, las reformas legislativas de 2012 y el II AENC no han constituido dos mundos incomunicados, como demuestra la negociación colectiva ordinaria.

\subsection{La continuación de la política de reformas "estructurales" del marco legal de la negociación colectiva en 2012, 2013 y 2014}

En el ámbito específico de las relaciones de empleo público (jurídico-privadas y jurídico-públicas), el Real Decreto-ley 20/2012, de 13 de julio, de medidas para garantizar la estabilidad presupuestaria y de fomento de la competitividad, abrió la vía a la reforma de la negociación colectiva en dicho ámbito con medidas excepcionales dirigidas al objetivo de reducir el déficit fiscal ordenado por las instituciones y métodos de la gobernanza económica de la Unión Europea, que redujeron considerablemente la autonomía colectiva limitando y condicionando el derecho constitucional a la negociación colectiva, en relación con el de libertad sindical, que reconoce el art. 37.1 de la Constitución Española. Entre esas medidas hay que destacar la reserva a las Administraciones públicas de la posible revisión unilateral de los convenios colectivos y acuerdos que afecten al personal laboral, "cuando excepcionalmente y por causa grave de interés público derivada de una alteración sustancial de las circunstancias económicas" así lo decidan los órganos de gobierno de las Administraciones Públicas -suspendiendo o modificando el cumplimiento de convenios colectivos o acuerdos ya firmados- "en la medida estrictamente necesaria para salvaguardar el interés público", entendiendo la norma 
legal reformadora la concurrencia de la causa -la "alteración sustancial de las circunstancias económicas"- cuando las Administraciones Públicas deban adoptar medidas o planes de ajuste, de reequilibrio de las cuentas públicas, o de carácter económico financiero para asegurar la estabilidad presupuestaria o la corrección del déficit público, debiendo informar de ello a las organizaciones sindicales (nuevo apartado 2 del art. 32 de la Ley 7/2007, de 12 de abril, del Estatuto Básico del Empleado Público, EBEP y disposición adicional segunda del Real Decreto-ley 20/2012). Se trata, como es fácil de comprobar, de una fórmula de "descuelgue" de los convenios, pactos y acuerdos colectivos "sin límites de materias y sin exigencias de consultas, salvo un deber de información de las organizaciones sindicales" que desconoce el valor vinculante de los convenios colectivos garantizado por el art. 37.1 CE (M. E. Casas y M. Rodríguez-Piñero, 2012, págs. 63-64).

Asimismo el Real Decreto-ley 20/2012 suprimió, temporal o definitivamente, la tradicional función de mejora de los convenios colectivos y acuerdos para el personal laboral y de los acuerdos y pactos para personal funcionario y estatutario mediante la particular técnica de "suspender" y dejar sin efecto sus cláusulas opuestas o de mejora de su regulación, convertida en imperativa e indisponible, sobre vacaciones y permisos, prestación económica por incapacidad temporal, derechos sindicales y demás medidas de "reordenación y racionalización" (reformas de los arts. 48 y 50 del EBEP y arts. 8.3, 9.7, 10 y 14 y 16 del Real Decreto-ley 20/2012, desaprobadas con contundencia por el citado $371^{\circ}$ Informe del Comité de Libertad Sindical de la OIT).

Por su parte, en la ordenación general de la negociación colectiva laboral las reformas de la Ley 3/2012 se prolongaron en normas posteriores, si bien ni en su ritmo ni en su capacidad reformadora han sido comparables con el incesante proceso reformador que ha actuado sobre la -en paradójica terminología de los modificar el art. 82.3 ET, únicamente para acomodar su regulación de los sujetos legitimados subsidiariamente para intervenir y negociar en representación de los trabajadores -en defecto de secciones sindicales con representación mayoritaria en los comités de empresa y delegados de personal de los centros de trabajo afectadosen el período de consultas integrado en el procedimiento de modificación e inaplicación a la empresa de los convenios colectivos a la del procedimiento de modificaciones sustanciales de condiciones de trabajo y demás supuestos de "flexibilidad interna" (medidas colectivas de movilidad geográfica y modificación sustancial de condiciones de trabajo, procedimientos de suspensión de contratos o reducción de jornada por causas económicas, técnicas, organizativas o de producción y de despido colectivo). El reformado párrafo quinto del citado art. 82.3 ET dispone que la "intervención como interlocutores ante la dirección de la empresa en el procedimiento de consultas corresponderá a los sujetos indicados en el artículo 41.4, en el orden y condiciones señalados en el mismo" (art. 9 de la Ley 1/2014 que modificó también los arts. 40.2, 41.4, 47.1, 51.(2 y) 4 ET; su art. 10 modificó el art. 64.2 y 6 de la Ley 22/2003, de 9 de julio, Concursal, relativo a la tramitación de los procedimientos de modificación sustancial de condiciones de 
trabajo de carácter colectivo, incluidos los traslados colectivos, y de suspensión o extinción colectivas de las relaciones laborales, una vez declarado el concurso).

La Sala de lo Social de la Audiencia Nacional había declarado que "la alternativa de negociación por centros", regulada en el RD 1483/2012, de 29 de octubre, por el que se aprobó el Reglamento de los procedimientos de despido colectivo y de suspensión de contratos y reducción de jornada (y el precedente Reglamento aprobado por RD 801/2011), incurría en "un ultra vires", que desbordaba "con mucho el mandato de la disposición adicional 19.2 de la Ley 3/2012", que configuraba legalmente el período de consultas como un único trámite procedimental a nivel de empresa, que no puede dividirse artificialmente entre varios centros de trabajo con la pluralidad consiguiente de comisiones negociadoras, (SSAN de 25 Julio 2012 y de 1 de abril de 2013). Añadiendo que esa negociación de consultas parcelada y separada, en fraude de ley, acarreaba la nulidad de la medida empresarial.

En la nuevamente reformada regulación legal, la consulta ha de llevarse a cabo en una única comisión negociadora integrada por un máximo de trece miembros en representación de cada una de las partes intervinientes en el periodo de consultas, aunque circunscrita a los centros afectados por el procedimiento de ser varios los centros de trabajo de la empresa. Esa composición numérica de la comisión negociadora se justifica por su "coherencia con el número de miembros de la comisión negociadora del convenio colectivo de empresa" (preámbulo, II, de la Ley 1/2014), lo que pone de manifiesto la permeabilidad de las fronteras entre la negociación colectiva de empresa de eficacia general y normativa regulada por el título III del ET y la consulta/negociación colectiva de empresa, también de eficacia personal general al participar los sujetos legitimados como negociadores pero de eficacia jurídica contractual, no regulada por dicho título III del ET. La comisión representativa Informes anuales sobre "perspectivas del empleo" de la OCDE"legislación de protección del empleo" (régimen de la contratación y de los despidos).

El Real Decreto-ley 5/2013, de 15 de marzo, de medidas para favorecer la continuidad de la vida laboral de los trabajadores de mayor edad y promover el envejecimiento activo, incluyó una disposición adicional sexta, totalmente ajena al objeto de dicha norma de urgencia como se verifica por su título, para cerrar la efectividad del régimen jurídico de las modificaciones e inaplicaciones a las empresas de convenios colectivos de eficacia general. Conforme a su regulación, la Comisión Consultiva Nacional de Convenios Colectivos quedó facultada para conocer de las solicitudes de inaplicación o modificación concernientes a empresas o centros de trabajo radicados en las Comunidades Autónomas que no hubieran constituido órganos autonómicos tripartitos equivalentes o suscrito convenios de colaboración con el Ministerio de Empleo y Seguridad Social, y en tanto no los constituyeran.

De mayor calado, el Real Decreto-ley 11/2013, de 2 de agosto, para la protección de los trabajadores a tiempo parcial y otras medidas urgentes en el orden económico y social, convertido después en Ley 1/2014, de 28 de febrero, volvió a de los trabajadores debe quedar constituida antes del inicio del periodo de consultas, 
sin que su falta de constitución impida la apertura ni el transcurso del periodo de consultas, ni, por tanto, la decisión extintiva empresarial, ni su constitución posterior alargue la duración de dicho período. La nueva reforma legal contiene sucesivas determinaciones, de orden y condición, para identificar al sujeto negociador representativo de los trabajadores en los procedimientos de flexibilidad interna y de despido colectivo, que incorpora a la regulación del art. 41.4 ET sobre el de modificaciones sustanciales de condiciones de trabajo, a la que se remite la regulación propia de los restantes procedimientos y desde el que se llega, si esa modificación afecta a condiciones de trabajo contenidas en convenios colectivos regulados en el título III del ET, a la regulación de este título sobre la modificación/inaplicación de los convenios colectivos de eficacia general.

Finalmente - de momento- el Real Decreto-ley 16/2013, ya citado, redujo los espacios de la negociación colectiva en la regulación del trabajo a tiempo parcial, prescindió de la anterior preferencia del convenio sectorial para la regulación que resta a la negociación colectiva en la materia, y suprimió la tradicional función de mejora del convenio colectivo, estableciendo límites absolutos a una regulación mas favorable de las condiciones de trabajo contraria a la flexibilización pretendida y permitiendo a la negociación colectiva regulaciones de peor condición [art. 12.5.c) ET; y art. 14.1 ET sobre el período de prueba en contratos temporales de duración determinada]. Abundó en regulaciones legales supletorias en defecto de convenio colectivo o acuerdo con los representantes de los trabajadores que favorecen las facultades de disposición empresariales (art. 34.2 ET sobre distribución irregular de la jornada).

\section{El marco constitucional del derecho a la negociación colectiva}

No es necesario reiterar que la negociación colectiva es la institución central de los sistemas de relaciones laborales, uno de los ejes fundadores del Derecho del Trabajo con el Estado, y una de sus instituciones básicas con el contrato y el poder empresarial, a los que corrige y limita. Pilar de la "democracia social" y de los sistemas jurídicos pluralistas, es institución determinante de la fortaleza o debilidad del sistema de relaciones laborales.

La evolución del derecho de la negociación colectiva desde la libertad de negociación, en la concepción liberal del derecho -pasando en algunos ordenamientos por su consideración de "principio general de derecho"-, hasta su conversión en derecho fundamental, integrado primero en el de acción o actividad sindical y dotado, mas tarde, de sustantividad propia, culminó en las constituciones europeas de tercera generación de los años 70 del pasado siglo (F. VALDÉS, 2009, pág. 957). En el conjunto del Derecho del Trabajo, desde la construcción primigenia de los esposos WEBB (1894), el derecho de negociación colectiva se dirige a restaurar en el plano colectivo el equilibrio que le falta en el plano individual ante la desigualdad fundamental en el contrato individual entre trabajador y empresario.

El derecho de negociación colectiva significa el reconocimiento de un poder social y jurídico de los trabajadores, ejercido a través de sus representantes, frente al 
poder de dirección empresarial e implica el equilibrio de esos poderes que el Estado, a través de la ley, debe garantizar ante la profundidad de las raíces de la desigualdad. De ahí que algunos ordenamientos reconozcan el derecho a la negociación colectiva como unilateral de los representantes de los trabajadores, de los sindicatos (y, en su caso, de órganos unitarios de representación), y en otros como bilateral, de representantes de los trabajadores y empresarios, debiendo entonces la ley operar el equilibrio, la corrección de la desigualdad entre los titulares del derecho, partiendo del mayor poder de partida del empresario. En esta línea el Convenio núm. 98 de la OIT sobre aplicación de los principios del derecho de sindicación y de negociación colectiva, derechos que considera inseparables, establece el deber de los Estados de adoptar, "cuando ello sea necesario", medidas de estímulo y fomento del pleno desarrollo y uso de procedimientos de negociación voluntaria entre las organizaciones de trabajadores y los empleadores y sus organizaciones con objeto de reglamentar, por medio de contratos colectivos, las condiciones de empleo (art. 4).

\subsection{El derecho a la negociación colectiva en la Constitución Española}

En la Constitución Española, el art. 37.1, en relación con el art. 28.1, reconocen el derecho a la negociación colectiva de los sindicatos como derecho integrante del contenido esencial del derecho fundamental de libertad sindical, que confiere al sindicato un amplio marco de libertad en el ejercicio de su acción de la que la negociación colectiva es instrumento necesario, primordial, en un Estado democrático ("resulta inimaginable que sin ella se logren desarrollar eficazmente" las funciones constitucionales del sindicato": STC 238/2005, FJ 3, entre otras muchas), y como derecho a la propia negociación colectiva de los representantes de los trabajadores y empresarios y a su resultado negocial, el convenio colectivo con fuerza vinculante. El art. 37.1 de la Constitución Española garantiza y ordena a la ley garantizar "el derecho a la negociación colectiva laboral entre los representantes de los trabajadores y empresarios, así como la fuerza vinculante de los convenios".

Como ha dicho el Tribunal Constitucional español, "el reconocimiento autónomo y diferenciado de la negociación colectiva en el art. 37.1 C.E., supone la superación de la mera idea de libertad de negociación, como esfera libre de injerencias, y asegura, mediante una tarea encomendada específicamente al legislador, un sistema de negociación y contratación colectiva y la eficacia jurídica del convenio colectivo. Al legislador le corresponde cumplir un papel activo en la concreción y desarrollo del derecho a la negociación colectiva, dando efectividad y apoyo al proceso de negociación y a su resultado, y, dentro de esa regulación, determinar quienes están legitimados para negociar y pactar en su caso el convenio colectivo en cada nivel o ámbito [...] (STC 208/1993, FJ 3). El derecho a la autonomía colectiva, y en concreto a la negociación colectiva, se reconoce en la Constitución como "columna vertebral" del sistema constitucional de relaciones de trabajo, ha dicho también el Tribunal Constitucional español (STC 178/1996, FJ 8).

El derecho fundamental de negociación colectiva asegura a los representantes de los trabajadores y empresarios un ámbito de libertad de negociación y de contratación para ejercer la facultad de regular sus intereses recíprocos mediante 
convenios colectivos dotados de fuerza vinculante, emanando esa facultad o "poder de autorregulación" contractual y la fuerza vinculante de los convenios de la propia Constitución, que, al tiempo, "ordena garantizarla[s] de manera imperativa al legislador ordinario" (STC 58/1985, FFJJ 3 y 4).

La ley, que configura libremente el derecho a la negociación colectiva según las opciones políticas mayoritarias, ha de hacerlo dentro del doble mandato constitucional de respetar su contenido esencial (art. 53.1 CE) y garantizar el derecho a la negociación colectiva y la eficacia vinculante del convenio (art. 37.1 $\mathrm{CE}$ ), asumiendo, como ha declarado el Tribunal Constitucional, una posición de colaboración activa o positiva destinada a promocionar, a asegurar la efectividad del derecho constitucionalmente reconocido, convirtiéndose así la ley en el complemento indispensable de la doble garantía que la Constitución incorpora (M. Rodríguez-Piñero, 1992, pág. 3). La ley de desarrollo del art. 37.1 de la Constitución no puede negar u obstaculizar el ejercicio de la facultad negociadora de los sindicatos, ni desconocer el espacio de libertad de negociación y la función de regulación laboral del derecho a la negociación colectiva, ni desvirtuar la eficacia "real" y no meramente obligacional de los convenios colectivos, inderogables e indisponibles por la autonomía contractual individual (F. Valdés, 2004, pág. 25). En otros términos, el derecho a la negociación colectiva de los representantes de los trabajadores y los empresarios y la fuerza vinculante de los convenios colectivos, que la Constitución reconoce y garantiza, imponen límites a la libertad de configuración del legislador democrático.

Pero el art. 37.1 de la Constitución despliega, al tiempo, una eficacia positiva sobre la ley, a la que impone también la función de garantizar el derecho constitucional, preservando la autonomía negocial y contractual de las partes, corrigiendo su situación real de desigualdad o déficit negocial, y tutelando la capacidad negociadora del sindicato para el que -ya ha quedado dicho la negociación colectiva es institución imprescindible en el desempeño de su función de defensa de los intereses de los trabajadores (de su función de representación institucional que le confieren los arts. 7 y 28 de la Constitución), y asegurando, también por la misma razón de garantizar el ejercicio efectivo de las funciones sindicales, la eficacia jurídica de los convenios colectivos alcanzados. Al cumplir con el mandato constitucional de hacer efectivo el derecho de negociación colectiva y la eficacia jurídica de los convenios colectivos la ley puede imponer exigencias o límites al derecho de negociación colectiva siempre que, respetado su contenido esencial, estén objetivamente justificados y sean proporcionales al fin garantizador señalado y al de otros derechos constitucionales. Así sucede, entre otras, y como es sabido, con las reglas legales que escapan "al poder de disposición de las partes negociadoras" e imponen exigencias "especialmente rigurosas" de representatividad a los sujetos sindicales y asociaciones empresariales legitimados para negociar convenios colectivos de eficacia general y contenido normativo, modelo de negociación colectiva legítimamente acogido por el Estatuto de los Trabajadores, "que en todo caso no agota la virtualidad del precepto constitucional" (STC 73/1984, FJ 2). En tal modelo paradigmático de negociación colectiva, el ET 
garantiza la fuerza vinculante de los convenios colectivos mediante el reconocimiento de fuerza normativa a los "pactos sustanciales" de los convenios y de un "plus de eficacia" personal (STC 108/1989, FJ 2). De ahí la referencia a la "relevancia cuasi-pública", al valor cuasi-legal, del convenio colectivo "estatutario" realizada con habitualidad por la jurisprudencia constitucional (SSTC 177/1988, FJ 4, y 119/2002, FJ 6).

Aunque, como bien ha reconocido la doctrina, la determinación de la extensión y límites del contenido esencial del derecho a la negociación colectiva entendido como libertad de negociación y de contratación, sin interferencias ni limitaciones injustificadas, es "una de las cuestiones mas delicadas y complejas" de cuantas afectan a la configuración constitucional de este derecho (F. Valdés, 2009, pág. 962), pendiente aún de su fijación por el Tribunal Constitucional, puede convenirse sin dificultad en que esa doble libertad comprende "el espacio vital de la negociación colectiva", esto es, y, de un lado, el poder de la autonomía colectiva de organización de su derecho y de ejercicio del mismo, de modo que a ese poder pertenece la elección del nivel y de las materias a negociar, la conclusión del convenio y su administración (F. Valdés, 2012 (1), págs. 119-121); de otro, la fijación "en general" del contenido de la relación laboral (STC 27/2004, FJ 4) y cuantas cuestiones afecten a los intereses económicos y sociales de los representados por los negociadores.

En cuanto a la fuerza vinculante de los convenios colectivos en relación con el derecho de libertad sindical, con reiteración ha dicho el Tribunal Constitucional español que esa fuerza vinculante constitucional, que el legislador debe garantizar, asegura materialmente la prevalencia de la voluntad colectiva sobre la individual de los afectados por el convenio y sobre la voluntad unilateral del empleador, aunque sin anular ésta, porque en nuestro sistema de relaciones laborales es compatible la libertad sindical, que significa el predominio de lo colectivo sobre lo individual, con la libertad de empresa, que cubre los poderes directivos del empresario y es un espacio abierto a la autonomía individual (STC 107/2000, FJ 7, y las sentencias que cita). La prevalencia de la autonomía colectiva y la consiguiente eficacia del convenio colectivo de sujetar imperativamente a los contratos individuales constituye, así, "un elemento de la configuración constitucional del derecho a la negociación colectiva como medio de acción sindical" (STC 225/2001, FJ 6), que se proyecta sobre la configuración del sistema normativo laboral (STC 107/2000, FJ 9). Esa prevalencia de la autonomía colectiva no impide, naturalmente, la modificación del convenio colectivo, esto es, la alteración de las condiciones pactadas, que es institución ordinaria en la vida del convenio colectivo en cuanto expresión de su esencial temporalidad, que no puede "petrificar" las condiciones de trabajo en ellos pactadas, sometidas "siempre a las fluctuaciones técnicas, organizativas, productivas o de cualquier otro orden que surgen por el paso del tiempo en las relaciones laborales como, en general, en todas las relaciones jurídicas". Impide la modificación del convenio colectivo por la autonomía individual al margen de los procedimientos previstos en los propios convenios colectivos y en la ley que -introduce aquí el Tribunal Constitucional 
consideraciones de legalidad ordinaria- han contado "siempre con la voluntad de la representación legítima de las partes" (SSTC 105/1992, FJ 6; 225/2001, FJ 4; 238/2005, FJ 4).

En cambio, no es elemento de la configuración constitucional del derecho específico a la negociación colectiva la intangibilidad o inalterabilidad de lo convenido, que no puede confundirse con la fuerza vinculante constitucionalmente garantizada, frente a la ley como fuente de regulación de las relaciones laborales, incluso frente a modificaciones legislativas sobrevenidas; el convenio colectivo se somete a la capacidad normadora de la ley estatal de los derechos y obligaciones laborales y sociales que constituyen el objeto del ordenamiento laboral (arts. 1.1, 9.2 y 35.1 de la Constitución) y a las demás normas de superior rango jerárquico, evidentemente a la Constitución y a los derechos fundamentales (STC 210/1990, FFJJ 2 y 3, y 62/2001, FJ 3; ATC 85/2011, FJ 7, y numerosos posteriores).

Será conveniente advertir que esta jurisprudencia constitucional se ha formado en el enjuiciamiento constitucional de disposiciones legales que no regulaban el régimen general del derecho a la negociación colectiva reconocido en el art. 37.1 $\mathrm{CE}$, ni nada disponían sobre la fuerza vinculante de los convenios colectivos "en general, ni, en particular" (ATC 85/2011, FJ 7). Sobre la fuerza vinculante de los convenios colectivos lo que el Tribunal Constitucional ha dicho es que "la sujeción del convenio colectivo al poder normativo del Estado, constitucionalmente legítima, no implica ni permite la existencia de decisiones administrativas que autoricen la dispensa o inaplicación singular de disposiciones contenidas en convenios colectivos, lo que no sólo sería desconocer la eficacia vinculante del convenio colectivo, sino incluso los principios garantizados en el art. 9.3 C.E." (STC 92/1992, FJ 4).

\subsection{El cambio del modelo legal de negociación colectiva de eficacia general: del derecho a la negociación colectiva al derecho a la libertad de empresa y la defensa de la productividad.}

Las normas reformadoras mas recientes del marco legal insisten en que tras ellas el modelo de negociación colectiva de eficacia general es más equilibrado. ¿Es cierto que las nuevas técnicas introducidas equilibran la influencia respectiva de las partes sobre el proceso de negociación garante del ejercicio efectivo de su derecho de libertad de negociación y contratación? La primacía de la autonomía colectiva y de la libertad de acción sindical sobre la autonomía individual y la libertad de empresa y la fuerza del convenio colectivo de vincular imperativamente a los contratos individuales de su ámbito de aplicación, ¿resultan tras las reformas del marco legal de la negociación colectiva garantizadas según una relación mas equilibrada o mejor compensada?

Naturalmente, los sindicatos han rechazado esa consideración y no han dudado en atribuir a las leyes reformadoras el efecto contrario: "una función desequilibrante de las posiciones negociales, a fin de articular una bajada en las condiciones laborales, retributivas y de tiempo de trabajo, que se venían negociando en los convenios colectivos, a favor del interés empresarial, sin tomar referentes vinculados a la competitividad empresarial o a la creación de empleo, sino a la mera 
maximización del beneficio", destacando que la atomización de la negociación a través de su obligatoria descentralización a la empresa, la inaplicación a las empresas de los convenios colectivos sectoriales a instancias únicamente del empresario, así como la pérdida de ultraactividad de los convenios colectivos, ha debilitado su posición negociadora (CCOO, págs. 38 y 50). La doctrina, con sus naturales discrepancias, reconoce que el cambio de orientación legal desde el derecho a la negociación colectiva hacia la libertad de empresa ha alterado el anterior equilibrio de posiciones de las partes en los procesos de negociación hacia una mayor debilidad negocial de las representaciones sindicales (R. Escudero, 2012, págs. 11 y ss.; J. Cruz, 2013, pág. 211; M. Rodríguez-Piñero, F. Valdés y M. E. Casas, 2013, págs. 27 a 32).

De hecho el ejercicio del derecho de negociación colectiva ha perdido la unilateralidad "de facto" que le caracterizó en sus etapas precedentes, actuando ahora la iniciativa empresarial a través de los nuevos dispositivos legales. A la unilateralidad sindical de las prácticas negociales dominante en nuestro sistema negocial tradicional ha sucedido la unilateralidad empresarial. Las denuncias de convenios colectivos por los empresarios, y sus iniciativas de modificación e inaplicación en las empresas de convenios colectivos aplicables, constituyen significativos ejemplos del protagonismo de los empresarios en la práctica de la negociación colectiva mas reciente. La iniciativa negocial de los sindicatos ha pasado a una fase de repliegue.

El legislador ha intervenido en el sistema de negociación colectiva de eficacia general y fuerza normativa regulado en el título III del ET para posibilitar el logro de los resultados pretendidos por la reforma del "mercado laboral". En el caso de la Ley $3 / 2012$, según su propia justificación (preámbulo, IV), el objetivo reformador general de "favorecer la flexibilidad interna en las empresas como alternativa a la destrucción de empleo" y a la dualidad del mercado de trabajo español, sostenido en el deber de los poderes públicos de velar por la defensa de la productividad (art. 38 $\mathrm{CE}$ ), se ha materializado en el desarrollo de la función de gestión del convenio colectivo como función principal, virtualmente exclusiva, de una negociación colectiva concebida como útil o instrumento de adaptación de las condiciones laborales a las circunstancias de las empresas en su triple dimensión de: 1) "facilitar la adaptación de los salarios y otras condiciones de trabajo a la productividad y competitividad empresarial"; 2) "facilitar una negociación de las condiciones laborales en el nivel más cercano y adecuado a la realidad de las empresas y de sus trabajadores"; y 3) adaptar el "contenido de la negociación colectiva a los cambiantes escenarios económicos y organizativos", evitando la "«petrificación» de las condiciones de trabajo pactadas en convenio" y la demora excesiva del acuerdo renegociador. Al logro de estos concretos propósitos reformistas se han destinado los mecanismos técnicos introducidos por la Ley 3/2012 para garantizar la efectividad, respectivamente, 1) de la inaplicación a la empresa de determinadas condiciones de trabajo previstas en el convenio colectivo de sector (o "descuelgue") o en el de la propia empresa ("autodescuelgue") o de su modificación mediante el arbitraje obligatorio de la Comisión Consultiva Nacional de Convenios Colectivos u 
órganos similares de las Comunidades Autónomas (arts. 82.3 y 41.6 ET); 2) de la descentralización de la negociación colectiva a la empresa mediante la ampliación de su espacio propio y el establecimiento de la prioridad aplicativa del convenio de empresa (o de grupo de empresas o de uniones de empresas), también sobre materias determinadas, con carácter indisponible para los acuerdos interprofesionales y convenios colectivos sectoriales de ámbito estatal o autonómico (art. 84.1 y 2 ET); y 3) de la revisión de los convenios colectivos durante su vigencia pactada, así como de su renovación, concluida esa vigencia, mediante la limitación temporal de su ultraactividad legal a un año de duración, salvo pacto en contrario (art. 86. 3 ET).

En dos de las técnicas utilizadas por la Ley 3/2012, cuales son el arbitraje público obligatorio como solución a los conflictos de inaplicación y modificación parciales de los convenios colectivos y la prioridad aplicativa del convenio de empresa como solución a la concurrencia conflictiva entre convenios colectivos, obligada para los acuerdos interprofesionales y los convenios colectivos sectoriales sobre estructura de la negociación colectiva, el legislador ha impuesto restricciones a la negociación colectiva para que ésta actúe sin desviaciones ni contradicciones con sus objetivos reformadores. Con tales restricciones, de distinta naturaleza e intensidad ciertamente, el perímetro del derecho de negociación colectiva, en su contenido de libertad de negociación, se estrecha y la fuerza vinculante del convenio colectivo se debilita al autorizar la ley la inaplicación singular de disposiciones del convenio a través de decisiones administrativas contra la voluntad de una de las partes.

La Ley 3/2012 no se ha propuesto reconocer nuevas facultades del derecho a la negociación colectiva, ni ha incorporado nuevos instrumentos a disposición de los negociadores para incentivar la adopción de acuerdos en garantía de la efectividad de su derecho de negociación colectiva y de la fuerza vinculante de los convenios colectivos [los mecanismos de naturaleza compositiva que preceden al arbitraje obligatorio proceden de la regulación del Real Decreto-ley 7/2011; otro tanto sucede con la regulación del art. 85.3, letra c), con las debidas adaptaciones al articulado de la Ley 3/2012]. En garantía de la libertad de empresa y de la defensa de la productividad (art. 38 de la Constitución Española, al que expresamente recurre su preámbulo) la Ley 3/2012 constriñe la autonomía colectiva y su poder organización del régimen jurídico de la propia negociación colectiva. Es la ley la que, para imponer a la negociación colectiva los resultados que se propone alcanzar, ejerce su poder sobre el poder o competencia de los negociadores, sobre el derecho a la negociación colectiva que asegura un ámbito de libertad que, además, la ley debe garantizar (art. 37.1 de la Constitución). La Ley 3/2012 desvirtúa también la eficacia jurídica del convenio colectivo, posibilitando su modificación e inaplicación parciales a las empresas sin el acuerdo de los sujetos titulares del derecho a la negociación colectiva, con lo que, con la perspectiva adicional del derecho fundamental de libertad sindical, corrige el predominio de lo colectivo y de la libertad sindical sobre la autonomía individual y la libertad de empresa, favorecida por el arbitraje público obligatorio que la Ley instaura. 


\subsection{Las técnicas jurídicas reformadoras de la negociación colectiva como instrumento de adaptación de las condiciones de trabajo a las necesidades empresariales}

Convendrá exponer con mayor detenimiento las técnicas introducidas por la Ley 3/2012 para conseguir su objetivo reformador y sus propósitos flexibilizadores del marco legal de la negociación colectiva de eficacia general.

\subsubsection{La prioridad aplicativa del convenio colectivo de empresa, indisponible por acuerdos interprofesionales y acuerdos y convenios colectivos sectoriales, estatales y autonómicos, sobre estructura de la negociación colectiva}

La Ley 3/2012 no se ha limitado a establecer la preferencia aplicativa de los convenios colectivos de empresa y para un grupo de empresas o una pluralidad de empresas vinculadas por razones organizativas o productivas y nominativamente identificadas con cualesquiera otros convenios, ya vigentes, de ámbito sectorial en supuestos de concurrencia convencional conflictiva -tiene que darse el presupuesto de la "afectación" del contenido de los convenios colectivos vigentes de ámbito sectorial por el posterior de empresa: art. 84.1 ET-, sino que prohíbe a los convenios colectivos sectoriales estatales y autonómicos y a los acuerdos interprofesionales sobre estructura de la negociación colectiva del mismo ámbito territorial estatal y autonómico (a "los acuerdos y convenios colectivos a que se refiere el art. 83.2" según tenor literal del art. 84.2, párrafo tercero, ET) disponer de dicha preferencia aplicativa en la serie de materias que relaciona, "primordiales para una gestión flexible de las condiciones de trabajo": retribuciones (cuantía del salario base y de los complementos salariales, incluidos los vinculados a la situación y resultados de la empresa; retribución de horas extraordinarias y específica del trabajo a turnos), tiempo de trabajo (horario y distribución, trabajo a turnos y planificación anual de las vacaciones), clasificación profesional en su adaptación a la empresa, modalidades de contratación también en su adaptación a la empresa por convenios de empresa, medidas de conciliación de la vida laboral, personal y familiar, y las demás condiciones de trabajo establecidas en convenios de empresas -o de grupo o de pluralidad de empresas vinculadas- a las que los acuerdos y convenios colectivos del art. 83.2 ET decidan otorgar preferencia aplicativa al ordenar la concurrencia entre convenios colectivos. Estos acuerdos y convenios interprofesionales y sectoriales, estatales y autonómicos, cuya función es precisamente establecer la estructura de la negociación colectiva y las reglas de solución de los conflictos de concurrencia entre convenios colectivos, pueden ampliar el ámbito material de la preferencia aplicativa legal de los convenios de empresa "respecto del convenio sectorial estatal, autonómico o de ámbito inferior", pero no constreñirla. Sin embargo, la prohibición de disponer de la prioridad aplicativa de la regulación los convenios de empresa sobre las materias dichas no afecta a los convenios sectoriales provinciales, ni a los de grupos de empresas o de uniones de empresas, dotados de igual preferencia aplicativa, pero para los que es disponible la preferencia aplicativa de los convenios de empresa. 
Naturalmente, la reformada regulación del art. 84.2 ET no obliga a negociar las materias señaladas en el nivel de empresa -o de grupo de empresas o de pluralidad de empresas vinculadas-, ni imposibilita su negociación en ámbitos superiores. El art. 84.2 ET no contiene una norma sobre estructura de la negociación colectiva, sino sobre concurrencia de convenios colectivos. El precepto legal reformado no exige a los acuerdos interprofesionales y convenios colectivos sectoriales de ámbito sectorial, estatales y autonómicos, fijar una estructura de la negociación colectiva en la que esa serie de materias se reserven necesariamente a la negociación colectiva de ámbito empresarial. No lo admitiría el art. 37.1 de la Constitución que garantiza la libertad de los negociadores de elegir el ámbito o unidad de negociación en que han de negociarse y adoptarse los acuerdos sobre las distintas materias. Ahora bien, si los convenios colectivos de empresa regulan dichas materias porque así lo han decidido los sujetos legitimados para negociar en tal ámbito [arts. 87.1 y 3.a) y b) y 88.1 y 4 ET], lo que además pueden hacer "en cualquier momento de la vigencia de convenios colectivos de ámbito superior" (art. 84.2, párrafo primero; jugando en ello la obligación legal de negociar de buena fe del art. 89.1 ET), su aplicación está dotada ex lege de una preferencia indisponible por los acuerdos y convenios colectivos interprofesionales y sectoriales, estatales y autonómicos, ordenadores de la estructura de la negociación colectiva, salvo para ampliarla materialmente, preferencia de aplicación que desplaza la de cualquier otro convenio de ámbito superior aplicable y, con ella, cualquier otra regla de solución de la concurrencia conflictiva de convenios colectivos ordenada por la ley (art. 84.1 ET, regla del prior in tempore salvo pacto en contrario; o art. 3.3 ET, principio de norma mas favorable) o por los acuerdos y convenios colectivos, estatales y autonómicos, que fijen la estructura de la negociación con carácter interprofesional o sectorial.

El principio legal de preferencia aplicativa del convenio de empresa prescinde de la lógica de la suplementariedad o de la norma mas favorable en la articulación de las relaciones entre convenios colectivos de sector y de empresa, así como de la lógica de la complementariedad, para permitir una negociación colectiva siempre mas abierta a las reivindicaciones empresariales y mas ajustada a su función de gestión flexible de las relaciones de trabajo en materias laborales tan capitales como las retribuciones y el tiempo de trabajo.

La prohibición legal de disposición de la preferencia aplicativa parcial de los convenios de empresas no se extiende a los acuerdos interprofesionales sobre materias concretas del art. 83.3 del ET. Ni aún en el supuesto de que su objeto material coincidiese con las condiciones de trabajo que, de estar reguladas en convenios colectivos de empresa, gozan de preferencia en su aplicación (p. e. medidas para favorecer la conciliación entre la vida laboral, familiar y personal de los trabajadores), la ley impide a los acuerdos sobre materias concretas disponer de esa prioridad aplicativa. A no ser que -contrariando los cánones de interpretación de un derecho constitucional de libertad que la ley ha de garantizar y confundiendo las reglas de estructura negocial y concurrencia de convenios- se entendiese que al hacerlo y establecer reglas para la solución de la concurrencia entre convenios de distinto ámbito esos acuerdos reúnen la doble naturaleza de ser, a un tiempo, 
acuerdos interprofesionales sobre materias concretas del art. 83.3 ET y acuerdos interprofesionales sobre estructura de la negociación colectiva del art. 83.2 ET.

En todo caso, la regla legal imperativa resta a los sindicatos y asociaciones empresariales mas representativos y representativos, estatales y de Comunidad Autónoma, libertad de decidir las funciones de los convenios de distinto ámbito en una estructura ordenada de la negociación colectiva y reduce imperativamente su libertad de negociación en ámbitos sectoriales e interprofesionales, contenida y protegida por su derecho constitucional de negociación colectiva, impidiéndoles ejercer, en su caso, su poder de control sobre la negociación colectiva de empresa en beneficio de ésta y de su función de gestión y, a la postre, de la libertad empresarial.

\subsubsection{La inaplicación singular a la empresa y la modificación de los convenios colectivos aplicables mediante arbitraje público obligatorio}

La solución a la falta de acuerdo entre los titulares de la autonomía colectiva en los conflictos sobre inaplicación en la empresa del convenio colectivo aplicable mediante la decisión dirimente de la Comisión Consultiva Nacional de Convenios Colectivos $\mathrm{u}$ órganos tripartitos y paritarios similares de las Comunidades Autónomas - directa o delegada a árbitros designados al efecto-, a petición de una de las partes y sin el acuerdo de la otra, constituye una restricción ciertamente intensa de la libertad de negociación colectiva y de la eficacia vinculante de los convenios colectivos.

Ante la imposibilidad de establecer un deber de acordar la Ley 3/2012 ha optado por un arbitraje público obligatorio tras el fracaso de los procedimientos de solución autónoma del desacuerdo. La decisión final de las discrepancias entre las partes negociadoras sobre la inaplicación a la empresa del convenio colectivo del sector o de la propia empresa en una serie de condiciones de trabajo que veremos, igualmente sensibles para las empresas y en parte coincidentes con las cubiertas por la regla de la preferencia aplicativa del convenio de empresa, se pone en manos de las Administraciones públicas dada la composición tripartita de los órganos administrativos a los que la Ley 3/2012 confiere la facultad de decidir la inaplicación de la regulación convencional vigente cuando concurran causas económicas, técnicas, organizativas o de producción. A través de esta decisión arbitral, a la que las partes quedan sometidas a instancia de una de ellas, se resuelven también los conflictos sobre la modificación de esas mismas condiciones de trabajo -o de otras siempre que su modificación sea sustancial- establecidas en los convenios colectivos de eficacia general (art. 41.6 ET).

Para favorecer la gestión empresarial del trabajo y su adaptación a las necesidades de productividad y competitividad empresariales el art. 82.3 ET, reformado por la Ley 3/2012, limita el derecho de negociación colectiva en dos operaciones tan exquisitamente pertenecientes a la autonomía colectiva y tan estrechamente vinculadas entre sí como la inaplicación y modificación de los convenios colectivos, que, en el caso de los acomodados al título III del ET y 
conforme sigue diciendo su art. 82.3, párrafo primero, "obligan a todos los trabajadores y los empresarios incluidos en su ámbito de aplicación y durante todo el tiempo de su vigencia", regla que, según el Tribunal Constitucional, "desarrolla a su vez el mandato establecido" en el art. 37.1 de la Constitución (STC 92/1992, FJ 4), y que el legislador excepciona, aunque el enunciado de la norma legal que contiene la excepción se inicie con la locución tradicional, mantenida en nuestro ordenamiento desde la Ley 11/1994, "sin perjuicio de lo anterior [...]. Y lo hace en un conjunto de condiciones de trabajo que pertenecen, también genuinamente, al ámbito material del derecho a la negociación colectiva: jornada de trabajo, horario y distribución del tiempo de trabajo, trabajo a turnos, sistema de remuneración y cuantía salarial, sistema de trabajo y rendimiento, funciones, mejoras voluntarias de la acción protectora de la Seguridad Social. Son condiciones de trabajo de las que, ha dicho el Tribunal Constitucional, que, atendiendo a su "trascendencia, importancia y significado", su modificación unilateral o por la autonomía de la voluntad individual "en masa" equivale a eludir o soslayar la función negociadora de los sindicatos o a vaciar sustancialmente de contenido efectivo el convenio colectivo (STC 238/2005, FJ 4). La fuerza vinculante del convenio, en cuya base está el acuerdo de voluntades, guarda, como es sabido, relación con la dimensión de afectación material de lo convenido (SSTC 105/1992 y 107/2000, 225/2001, 7).

La intromisión de la Administración en el derecho negociación colectiva es de particular importancia, pues, además de clausurar la negociación a petición de una de las partes negociadoras contra la voluntad de la otra, que, de tratarse del sindicato, ejerce su derecho de libertad sindical que incluye -según jurisprudencia constitucional reiterada- el respeto del resultado alcanzado en el correspondiente proceso de negociación, la decisión dirimente o arbitral administrativa, cuya eficacia es la de los acuerdos alcanzados en períodos de consultas, deberá, como éstos, "determinar con exactitud las nuevas condiciones de trabajo aplicables en la empresa y su duración, que no podrá prolongarse más allá del momento en que resulte aplicable un nuevo convenio en dicha empresa". Como los acuerdos de consultas, las resoluciones arbitrales de las Administraciones públicas -o de los árbitros por ellas designados-no podrán "dar lugar al incumplimiento de las obligaciones establecidas en convenio relativas a la eliminación de las discriminaciones por razones de género o de las que estuvieran previstas, en su caso, en el Plan de Igualdad aplicable en la empresa" (art. 82.3, párrafos octavo y sexto, ET).

El enfoque del legislador reformador ha girado una vez más desde el derecho a la negociación colectiva hacia el derecho a la libertad de empresa. En la regulación del reformado art. 82.3 ET ese enfoque toma cuerpo en las causas económicas, técnicas, organizativas o de producción que justifican la inaplicación del régimen convencional aplicable a la empresa y que el precepto legal define en los mismos términos que utiliza para determinar las causas, de igual naturaleza, que permiten al empresario suspender los contratos de trabajo o reducir las jornadas ex art. 47 ET. Esta identidad conceptual es coherente con la lógica reformadora del ordenamiento laboral -desde el Real Decreto-ley 10/2010, sucedido por la Ley 35/2010- en el que la negociación colectiva es también un instrumento de "flexibilidad interna", que 
participa de la consideración general atribuida a dichos instrumentos de constituir "una alternativa positiva frente a medidas de flexibilidad externa que implican un ajuste en el volumen de empleo" (preámbulo, II, y capítulo II, "Medidas para favorecer la flexibilidad interna negociada en las empresas y para fomentar el uso de la reducción de jornada como instrumento de ajuste temporal de empleo", de la Ley 35/2010).

Ley 3/2012 amplió el supuesto de inaplicación en la empresa de los convenios colectivos aplicables y sus causas, desde la inaplicación únicamente del "régimen salarial previsto en los convenios colectivos de ámbito superior a la empresa" (regulación del supuesto en el Real Decreto-ley 7/2011), hasta la inaplicación de la serie de materias antes dichas "previstas en el convenio colectivo aplicable, sea este de sector o de empresa", y por las adicionales causas técnicas, organizativas o productivas señaladas, que habilitaban ya en la regulación de 2010-2011 la modificación de los convenios colectivos estatutarios, especialmente los de empresa, entre otras condiciones de trabajo, sobre jornada, horario y distribución del tiempo de trabajo, régimen de trabajo a turnos, sistema de remuneración, sistema de trabajo $\mathrm{y}$ rendimiento y funciones. La modificación sustancial de las condiciones establecidas en los convenios colectivos de sector sólo podía afectar al horario y distribución del tiempo de trabajo, régimen de trabajo a turnos, sistema de remuneración, sistema de trabajo y rendimiento y funciones y debía tener un plazo máximo de vigencia que no podía exceder de la vigencia del convenio colectivo sectorial modificado (art. 41.6 ET, reformado por el Real Decreto-ley 7/2011).

Además, las normas reformadoras de 2012 calificaron la causa económica de la inaplicación de los convenios colectivos de diferente modo a como lo había hecho el Real Decreto-ley 7/2011. Si en aquella norma de urgencia la causa económica se identificaba con "una disminución persistente" del nivel de ingresos de la empresa o con la afectación negativa "de su nivel de ingresos o su situación y perspectivas económicas [...] afectando a las posibilidades de mantenimiento del empleo en la misma", en la Ley 3/2012 tiene mayor amplitud y pretensión de automatismo: "Se entiende que concurren causas económicas cuando de los resultados de la empresa se desprenda una situación económica negativa, en casos tales como la existencia de pérdidas actuales o previstas, o la disminución persistente de su nivel de ingresos ordinarios o ventas. En todo caso, se entenderá que la disminución es persistente si durante dos trimestres consecutivos el nivel de ingresos ordinarios o ventas de cada trimestre es inferior al registrado en el mismo trimestre del año anterior". Y se ha desligado de su efecto negativo sobre el mantenimiento del empleo. De modo que, aunque la Ley 3/2012 destine parte de sus medidas (las de su capítulo III), y entre ellas ésta, a "incentivar la flexibilidad interna en la empresa como medida alternativa a la destrucción de empleo", el mantenimiento del empleo deja de ser un bien jurídico a proteger y ponderar en la apreciación de su concurrencia (y en la de las nuevas causas técnicas, organizativas y de producción), con lo que su mantenimiento, al que formalmente se dirigen las medidas inaplicativas o modificativas de los convenios colectivos, no opera materialmente como límite a la decisión empresarial. Ni se exigen del empresario compromisos de mantenimiento del 
empleo, ni de ser impuestos éstos por la propia negociación colectiva ("negociación decisional" o sobre decisiones económicas), es segura su eficacia jurídica.

Cambió también en la regulación legal vigente la duración del "descuelgue", que se desprende de topes máximos y se alarga en un horizonte impreciso ("no podrá prolongarse más allá del momento en que resulte aplicable un nuevo convenio en dicha empresa"), y ha desaparecido la mirada de la regulación anterior hacia la progresiva recuperación de las condiciones salariales temporalmente inaplicadas a la empresa.

Con todo, la diferencia más relevante entre la regulación precedente y la actual radica en el sometimiento por esta última de las controversias de inaplicación a la empresa y de modificación de los convenios colectivos estatutarios al arbitraje obligatorio de órganos públicos para hacer efectiva una y otra.

Calificada generalmente por la doctrina la norma contenida en el reformado art. 82.3 ET como absolutamente imperativa o "techo de protección" de los trabajadores (por todos, J. M. Goerlich Peset, 2013, págs. 60, 74-75 y 88-90), no considero que esas calificaciones sean adecuadas a su naturaleza de norma laboral compleja, reconocedora de derechos a los empresarios con carácter dispositivo y a los trabajadores con carácter de derecho necesario relativo o mínimo y -en otros contenido- como norma absolutamente imperativa. La norma legal reformada es, sin duda, autosuficiente $\mathrm{y}$, en tal sentido, posee una eficacia que podemos llamar "coactiva"; se aplica inmediatamente, sin necesidad de negociación colectiva. Pero no impide a ésta disponer de su regulación, pudiendo los convenios colectivos clausurar la posibilidad de su inaplicación o modificación durante su vigencia o someter esa inaplicación o modificación al acuerdo de las partes negociadoras alcanzado en las distintas instancias (período de consultas, comisión paritaria, mecanismos de solución autónoma de los conflictos de los acuerdos interprofesionales estatales o autonómicos) del procedimiento de inaplicación regulado en el citado art. 82.3 ET. Por su parte, el art. 41.4 ET, al que se remite expresamente el art. 82.3, párrafo segundo, de la misma norma legal, salva expresamente "los procedimientos específicos que puedan establecerse en la negociación colectiva". Sin embargo, no es éste tema para entrar a desarrollar aquí con el detenimiento debido.

\subsubsection{La limitación temporal de la eficacia ultraactiva de los convenios colectivos}

En el caso de la limitación temporal de la eficacia ultraactiva de los convenios colectivos estatutarios no es que la Ley 3/2012 no aplique a la negociación colectiva su determinación reformadora con el propósito, en este punto, de garantizar la renovación de los convenios en plazos razonables. Lo ha hecho, sin embargo, operando sobre una institución legal, pues tal es la naturaleza de la eficacia ultraactiva del convenio colectivo que prorroga su contenido normativo tras su denuncia y vencimiento en defecto de pacto de contrario (art. 86.3, párrafo segundo, ET). Y, contra los modos imperativos y autosuficientes de normar en que 
se expresa en otras ocasiones su comportamiento reformador, ha utilizado aquí las técnicas tradicionales de la flexibilización normativa, esto es, la ley mantiene su naturaleza de norma dispositiva, y deja a la propia negociación colectiva el mantenimiento indefinido, con duración distinta a la legal, o la completa supresión, de la vigencia ultraactiva de los convenios colectivos y, en su caso, la fijación de los efectos de la pérdida de esa vigencia, limitándose a establecer, con carácter supletorio, la regla de la aplicación del convenio colectivo de ámbito superior, si lo hubiere, para cubrir el vacío convencional en defecto de solución al vacío por la propia autonomía colectiva (art. 86.3, en especial párrafos cuarto, primero y segundo, ET).

La ley reformadora, en el cumplimiento de su función de garantía institucional del derecho a la negociación colectiva y de la fuerza vinculante de los convenios colectivos que le impone el art. 37.1 CE, ha acogido una opción política diferente de la del legislador anterior. Se ha retirado en parte, y dejado de salvaguardar, con carácter supletorio, la eficacia vinculante de los convenios colectivos en los procesos de renovación convencional más allá del período de un año desde su denuncia para situarla en el terreno de la propia negociación colectiva. A ésta corresponde, como no podía ser de otra manera en un sistema de autonomía colectiva, el régimen de la eficacia temporal de los convenios colectivos, también de la eficacia temporal de dichos convenios una vez denunciados y concluida su duración pactada $\mathrm{y}$, ahora, la solución de los problemas que a la negociación colectiva plantea la retirada de la precedente regulación legal que aseguraba, también con carácter supletorio, la eficacia ultraactiva indefinida de los convenios colectivos estatutarios denunciados y vencidos, hasta su sustitución por un nuevo convenio colectivo de naturaleza estatutaria o extraestatutaria.

Conforme al reformado art. 86.3, párrafo cuarto, ET: "Transcurrido un año desde la denuncia del convenio colectivo sin que se haya acordado un nuevo convenio o dictado un laudo arbitral, aquél perderá, salvo pacto en contrario, vigencia y se aplicará, si lo hubiere, el convenio colectivo de ámbito superior que fuera de aplicación".

Cierto es que la garantía supletoria para cubrir el vacío convencional resultante del agotamiento de la ultraactividad del convenio colectivo mediante la aplicación del convenio de superior ámbito territorial o funcional, que el precepto legal reformado ofrece, puede resultar de escasa utilidad ante las deficiencias de la estructura de la negociación colectiva española, en la que no abundan los convenios sectoriales estatales ni las prácticas de coordinación entre los diferentes niveles territoriales y funcionales de negociación en los distintos sectores de actividad. Las organizaciones sindicales y empresariales más representativas y suficientemente representativas en los sectores tienen aquí una importante tarea que realizar, poniendo fin a esas deficiencias y acomodando la estructura negocial a las necesidades planteadas por la nueva regulación legal (art. 83.2 ET). También la tienen, como acabo de señalar, en la ordenación misma de la ultraactividad y de los efectos de su pérdida, dada la naturaleza dispositiva de la regulación legal y la insuficiencia de su garantía supletoria -puede que el convenio colectivo de superior ámbito no exista o que, aun existiendo, la extensión de su contenido material sea 
menor a la del convenio colectivo que ha perdido vigencia- , a través de acuerdos interprofesionales (art. 83.3 ET) en los que sea visible una mayor decisión que la mostrada en el Acuerdo de 23 de mayo de 2013 de la Comisión de Seguimiento del II Acuerdo para el empleo y la negociación colectiva sobre ultraactividad de los convenios colectivos.

Cierto es también que la reformada regulación legal ha presionado sobre los procesos de renovación convencional abiertos antes y después de su entrada en vigor, debilitando la posición de los negociadores sindicales y contribuyendo al intenso proceso de moderación y reducción salarial -especialmente para los trabajadores de nueva contratación- y de decaimiento de la tasa de cobertura de la negociación colectiva, ya apuntados al comienzo de este ensayo.

La retirada de la ley en el ejercicio de su función constitucional de garantía del derecho a la negociación colectiva a través de la defensa de ultraactividad de los convenios colectivos, institución al servicio de la efectividad del derecho constitucional, ha obedecido, una vez mas, a la mutación advertida del objeto de la tutela de la legislación reformadora de 2012 desde el derecho a la negociación colectiva al derecho a la libertad de empresa, que, en este punto, se traduce en la ampliación del espacio de la autonomía contractual individual, libre de la fuerza vinculante del convenio colectivo indisponible por aquélla, y a la postre en el incremento de los poderes empresariales de disposición, así como en la acentuación de la función de la negociación colectiva de gestión o adaptación de las condiciones de trabajo a la realidad de cada momento.

Sin embargo, la nueva regla legal contenida en el párrafo cuarto del art. 86.3 ET no estaría debidamente interpretada, con la perspectiva de obligada interpretación de las leyes de conformidad a la Constitución (arts. 37.1 y 28.1), si se entendiera dirigida a "crear vacíos convencionales, a reducir el grado de cobertura de los convenios colectivos, a reforzar el poder contractual del banco económico o, en fin, a sustituir los espacios de la autonomía colectiva por el ejercicio libérrimo de la libertad de empresa" (M. E. Casas, M. Rodriguez-Piñero y F. Valdés, 2013, pág. 4).

La nueva regulación legal no puede dificultar sustancialmente el derecho constitucional a la negociación colectiva entendido como libertad de negociación y contratación ejercida, también como manifestación del derecho fundamental de libertad sindical, en el proceso de renovación convencional. En el plano de la legislación ordinaria, la obligación legal de negociar de buena fe (art. 89.1 ET), hecha valer con firmeza por los jueces y tribunales, debe contribuir a evitar las obstaculizaciones y obstrucciones indebidas, y en su caso antisindicales, en los procesos negociales. La regulación legal reformada tampoco puede favorecer los vacíos negociales, ni entorpecer la existencia de convenios colectivos, ya que, de ser así interpretada, la ley actuaría contradiciendo la función de garantía del derecho constitucional a la negociación colectiva que la Constitución le impone.

Del silencio de art. 86.3, párrafo cuarto, ET sobre los efectos de la pérdida de ultraactividad del convenio colectivo de no haber nuevo convenio, o laudo arbitral, o convenio colectivo de ámbito superior aplicable, no se desprende la completa y automática desaparición de las condiciones de trabajo del convenio colectivo 
definitivamente extinto con la pérdida de su eficacia ultraactiva. El convenio colectivo desaparece ciertamente, pero sus condiciones de trabajo no desaparecen con él, pues forman parte de los contratos individuales de trabajo celebrados y ejecutados bajo una determinada disciplina convencional colectiva que el contrato ha incorporado, incluso sin necesidad de remisión formal al convenio colectivo, o respecto de la que el contrato ha establecido condiciones mas favorables o distintas [arts. 1.091 y 1.251 a 1289 del Código Civil y art. 3.1.c) ET]. Los contratantes han definido el objeto de su contrato, las obligaciones recíprocas del trabajador y del empleador, con las condiciones de trabajo del convenio colectivo vigente al tiempo de contratar, que actúan como condiciones dinámicas al amparo de la sucesión en el tiempo de los convenios colectivos (clasificación profesional, funciones, tiempo de trabajo, lugar de trabajo, salario...). Desaparecido el convenio colectivo por su pérdida definitiva de vigencia, esas condiciones no están ya protegidas por la indisponibilidad asegurada por su fuerza vinculante (arts. 37.1 CE y 82.3, párrafo primero, ET), ni por el instituto de la condición mas beneficiosa individualmente adquirida que el convenio colectivo no crea -sin perjuicio de que algunas puedan estarlo a título personal, o estarlo todas contando con el consentimiento empresarial para que así sea-, sino por el propio contrato de trabajo, cuyo cumplimiento no puede quedar al arbitrio de uno de los contratantes (art. 1.256 Código Civil).

Del art. 86.3, párrafo cuarto, ET, y del agotamiento de la ultraactividad del convenio colectivo, se desprende la ampliación del margen de actuación de la autonomía contractual individual respecto de condiciones de trabajo que, extinguido aquél y su fuerza vinculante constitucional, son disponibles por ésta. Ello sin perjuicio del espacio de operación de la autonomía colectiva, pues la unidad de negociación no desaparece con el convenio colectivo que ha agotado el plazo legal de ultraactividad y la obligación legal de negociar sigue activa, ya que se sigue tratando de "revisar un convenio ya vencido" (art. 89.1, párrafo segundo, ET); y sin perjuicio de las facultades de información y consulta legalmente reconocidas a las representaciones unitarias de los trabajadores en las empresas y a los delegados sindicales por los arts. 64.5, párrafo segundo, ET y $10.3 .1^{\circ}$ LOLS.

En definitiva, el agotamiento de la eficacia ultraactiva del convenio colectivo no genera un "vacío regulador", sino un espacio de operatividad de la autonomía colectiva, más apremiante si cabe por la anomalía que significa en el ejercicio efectivo de un derecho constitucional, y también de la autonomía individual, "no siendo admisible, desde la lógica constitucional, crear un desierto normativo que sujete al trabajador a imposiciones unilaterales del empleador, que, en orden a la regulación de las condiciones de trabajo, se coloca formalmente en el mismo nivel que el trabajador individual", precisando para su modificación de la voluntad de éste [art. 3.1.c) ET] y de la participación de sus representaciones colectivas (M. E. Casas, M. Rodriguez-Piñero y F. Valdés, 2013, pág. 12).

No obstante lo dicho, es sabido que la interpretación de la silente regulación legal de los efectos del agotamiento de la ultraactividad de los convenios colectivos sin cobertura convencional colectiva (o equivalente: laudo arbitral) ha dado lugar a un rico e intenso debate doctrinal, con posiciones enfrentadas bien conocidas ( $\mathrm{S}$. 
Olarte, 2013, págs. 219 a 225): desde las que han equiparado la pérdida de vigencia definitiva del convenio colectivo y de las condiciones de trabajo en él contenidas con la derogación de la ley dada la eficacia normativa del convenio estatutario en el ordenamiento español (aplicando el principio de orden normativo del art. 86.4 ET), hasta las que, contrariamente, han defendido la integración de aquellas condiciones convencionales en los contratos individuales de trabajo ("contractualización") a título de condiciones mas beneficiosas dotadas de la protección novatoria que impide su libre modificación unilateral por el empresario (art. 41 ET).

La jurisprudencia de la Sala Cuarta del Tribunal Supremo decidirá esos efectos en los casos en que no lo hayan hecho las partes negociadoras o las confederaciones sindicales y empresariales en los instrumentos convencionales que tienen a su disposición a tal fin (art. 82.3 ET), y fijará y unificará la interpretación de la ley.

La doctrina se ha ocupado de analizar las decisiones, en ocasiones contradictorias, de las Salas de lo Social los Tribunales Superiores de Justicia y de la Audiencia Nacional (por todos, C. San Martin Mazzucconi, 2014 págs. 223 a 236).

\subsubsection{La rigidez de la ley flexibilizadora}

En fin, y con excepción de lo expuesto sobre la regulación legal de la ultraactividad de los convenios colectivos y, con las diferencias señaladas, de su modificación e inaplicación singular en las empresas, las leyes reformadoras blindan su regulación material para garantizar la flexibilidad introducida, el espacio de la autonomía individual y las facultades de gestión empresariales al amparo de la libertad de empresa. Con el resultado paradójico de que, para flexibilizar, la ley se hace rígida en favor de las facultades de decisión empresariales.

La ley fija nuevos modos de articular sus relaciones con la negociación colectiva: lejos ya la década de los años 90 del pasado siglo en que la ley laboral cedió nuevos territorios a la negociación colectiva para que ésta se encargase de flexibilizar su regulación y se tornó dispositiva (A. Supiot, 1996, pág. 641), operación estratégica del legislador que obviamente no conllevaba "compromiso alguno de irreversibilidad" (L.E. de la Villa, 1997, pág. 79; 2012, pág. 9), en esta nueva etapa reformadora la ley se ha encargado de flexibilizarse y de flexibilizar a la negociación colectiva para que ésta no se resista a los cambios y no corrija ni se desvíe de los objetivos del legislador o, si lo hace, deba contrarrestar la eficacia inmediata de la regulación legal. Lo advirtió con claridad meridiana la Ley 3/2012 al reconocer, como se recordará, que sus modificaciones en materia de negociación colectiva respondían a la finalidad de hacer de ésta un instrumento, y no un obstáculo, para adaptar las condiciones laborales a las concretas circunstancias de la empresa (preámbulo, IV), lo que fue tanto como anunciar la flexibilización de la negociación colectiva por la ley sin esperar a que la propia negociación colectiva asumiese y ejecutase los propósitos reformadores del legislador, incluso sin necesidad de negociación colectiva y contra los resultados de la propia autonomía colectiva (separándose así de la línea de las reformas del Real decreto-ley 7/2011). En las reformas últimas, es la ley la que ha juzgado conveniente a sus fines expresar 
sus mandatos a través de normas de eficacia inmediata y, en su caso, imperativas, aunque revertidas ahora hacia los intereses empresariales, y, como antes, sin compromiso alguno de irrreversibilidad ante la libertad de configuración del legislador democrático dentro de la Constitución.

Para efectuar esta nueva operación flexibilizadora la ley bien se desprende de la colaboración aplicativa de la negociación colectiva, bien se hace imperativa y establece regulaciones de derecho necesario absoluto de las que la negociación colectiva no puede disponer, bien establece prohibiciones y traza límites a la negociación colectiva, o bien permite a la negociación colectiva establecer reglas distintas, no necesariamente mas favorables que las legales, en ocasiones abiertamente menos favorables para los trabajadores y mas favorables para los empresarios. El recurso por la ley al mecanismo de su configuración supletoria "en defecto de acuerdo colectivo", que permite una negociación colectiva "derogatoria" de la ley, pero basada en la idea de proporcionar a los trabajadores una mayor protección o una protección equivalente a la deparada por la ley por la existencia de contrapartidas (p. e. sobre empleo), ha experimentado también un significativo descenso en las ultimas reformas legislativas. En síntesis, la ley agota la función reguladora de la materia laboral y prescinde de la negociación colectiva, cuya función tradicional de completar y mejorar la regulación legal deviene no sólo innecesaria, sino también perturbadora y retardataria de los objetivos reformistas, e impone limites de derecho necesario absoluto a su actuación e incluso a la de la autonomía individual (p.e. períodos de consultas en las decisiones de reorganización y reestructuración empresariales, también aquí con divergencias doctrinales en la apreciación de la intensidad imperativa de la ley, que la jurisprudencia ha comenzado a resolver favoreciendo el espacio de la negociación).

$\mathrm{La}$ incertidumbre que naturalmente resulta de la operación legal de confiar las medidas de flexibilidad interna a los convenios y acuerdos colectivos a través de las conocidas "cláusulas de reenvío" y a la propia negociación colectiva en las empresas ("flexibilidad negociada"), y la imprevisión de las decisiones judiciales de interpretación de las nuevas normas, se han considerado elementos de rigidez que las leyes reformadoras han pretendido evitar con una rigidez de nuevo cuño: con mandatos normativos automáticos y rígidos que aseguren la realización efectiva de sus fines -colocando a la negociación colectiva en la necesidad de neutralizarlos o, lisa y llanamente, impidiéndole hacerlo-, y que no dejen lugar a la imprevisibilidad resultante de su interpretación judicial. Es conocido que, en este último extremo, el objetivo del legislador no se ha visto correspondido con la realidad -los propios enunciados normativos en algunos casos se han encargado de frustrar el objetivo, de modo que puede decirse, sin exageración que asistimos a una etapa de activismo o "creacionismo" judicial en la interpretación y aplicación de las nuevas disposiciones legales.

Eso sí, la ley reformadora ha potenciado la función de gestión de la negociación colectiva vinculándola a la realización inmediata de sus decisiones. 


\section{Conclusiones: las transformaciones del sistema de relaciones laborales. Un nuevo modelo de comportamiento de los actores}

Las reformas expuestas del marco legal de la negociación colectiva de eficacia general en España han respondido a una diferente opción política del legislador, que ha incorporado un cambio de enfoque sustancial en el que la negociación colectiva se contrae y pierde significación en su consideración de institución cardinal del sistema constitucional de relaciones laborales al resultar afectada en su autonomía, en sus funciones y en la fuerza vinculante de sus resultados negociales, y se potencia, en cambio, en la de instrumento de flexibilidad interna para la adaptación de las condiciones de trabajo a las necesidades empresariales y a los requerimientos del mercado. Al amparo de la libertad de empresa y de la defensa de la productividad las reformas legales de 2012-2014 han avanzado el proceso de flexibilización de la negociación colectiva (iniciado en 1994 e intensificado en 2010-2011) y han ampliado el poder de decisión del empresario frente a la propia negociación colectiva y a la función negociadora de los sindicatos. Dichas reformas proyectan sus efectos sobre el sistema de relaciones laborales en su conjunto, marcando líneas de transformación de innegable trascendencia jurídica, más allá de sus consecuencias inmediatas y a corto plazo.

Línea de transformación capital y explicativa de todas las demás es, sin duda, la que ha intensificado la función de gestión de la negociación colectiva -su "capacidad de reacción" en términos del "Informe" del MESS "de evaluación del impacto de la reforma laboral"- en detrimento de su función clásica de regulación colectiva de las condiciones de trabajo lógicamente adaptada a las particularidades de los sectores y de las empresas (F. Valdés, 2012 (2), pág. 226). Las modificaciones legislativas analizadas del marco regulador de la negociación colectiva no han reforzado la finalidad de ésta de compensar la desigualdad estructural en las relaciones de trabajo, que ha crecido exponencialmente en España durante la crisis económica hasta producir la mayor brecha social entre ricos y pobres de los países desarrollados (según el reciente Informe de la OCDE, Society at a Glance 2014. The crisis and its aftermath, marzo, 2014), ni tampoco su función de reconocer nuevos derechos a los trabajadores relacionados con el empleo y para después del empleo como consecuencia de las políticas conocidas con el nombre de "flexiguridad" o "flexiseguridad", que pretenden equilibrar la necesaria flexibilidad empresarial con la debida seguridad de los trabajadores. Al contrario, presionan sobre la organización y comportamiento de la negociación colectiva como sistema flexible de adaptación de las condiciones de trabajo a los cambios económicos y organizativos, a las necesidades de los sectores y, particularmente, de las empresas. Las funciones del derecho a la negociación colectiva y de los convenios colectivos se retraen así a su dimensión de gestión de las necesidades empresariales.

Tan crucial o más que la anterior por sus consecuencias estructurales, y porque en ella se dan también cita todas las demás y es a ella a la que primordialmente sirve la función de gestión del convenio colectivo, es la línea de evolución que marca el declive del diálogo social y de la negociación colectiva sectorial y la 
promoción de la negociación colectiva de empresa y de grupo de empresas (estatutaria y extraestaturaria). Las finalidades de los convenios colectivos de sector de garantizar la concurrencia empresarial, fijar condiciones sectoriales mínimas e iguales de trabajo, ordenar la estructura de la negociación colectiva y proporcionar cobertura a las empresas sin convenio colectivo propio, decaen ante el favor que la ley dispensa a la negociación colectiva de empresa como garantía de flexibilidad, de competitividad y de proximidad a las necesidades de las empresas, tanto para aplicarles una regulación convencional singular, que les sea propia, de condiciones de trabajo esenciales para los objetivos empresariales (retribuciones y tiempo de trabajo), como para inaplicarles la regulación convencional del sector, que de este modo les es ajena, sobre virtualmente las mismas condiciones de trabajo decisivas para su gestión flexible. A este fin responde la atribución de preferencia negociadora y aplicativa al convenio de empresa por una regulación legal de orden público que ha extraido del poder de autorregulación de los negociadores sectoriales e interprofesionales el gobierno del sistema de negociación colectiva (art. 84.2 ET); y las posibilidades que la ley ofrece a las empresas de emanciparse de la regulación de los convenios de sector e, incluso, de los propios convenios de empresa, a través de su inaplicación o modificación por acuerdos de empresa (de consultas; modificables a su vez por la vía del art. 41.2 ET) o por decisiones arbitrales públicas con igual eficacia que los acuerdos de consultas, incluida la decisión final emanada del arbitraje público obligatorio que la Ley 3/2012 ha instaurado para hacer efectiva la inaplicación y modificación en la empresa de la regulación de los convenios colectivos de eficacia general o estatutarios (art. 82.3 ET).

La composición obligatoria del desacuerdo negocial por decisiones arbitrales administrativas que autorizan la modificación del convenio o su inaplicación singular a la empresa sustituye a la autonomía colectiva, rompe la concepción del convenio colectivo como resultado de una negociación hecha de concesiones recíprocas y su equilibrio, y quiebra su fuerza vinculante, devaluando el papel del acuerdo de las partes en la disponibilidad del convenio colectivo, en línea con la general depreciación de los acuerdos por la reformada regulación legal de las restantes instituciones de flexibilidad interna, al resultar innecesarios para la adopción por el empresario de sus decisiones de gestión del trabajo y de la empresa (modificaciones sustanciales de condiciones de trabajo, movilidad geográfica, suspensiones del contrato y reducciones de jornada, despidos).

La atracción por la descentralización de la negociación colectiva a la empresa, fenómeno común a distintos países de la Unión Europea sobre el que las leyes vienen actuando desde hace tiempo, especialmente si se consideran los acuerdos de empresa parte del derecho común de negociación colectiva, exalta la concepción del convenio colectivo $-\mathrm{y}$ de otros acuerdos de empresa como instrumento de flexibilidad interna, de gestión flexible de las condiciones de trabajo subordinada a los intereses económicos, técnicos, organizativos y productivos del empresario, ajustada a su continua evolución, en busca permanente de productividad y competitividad, e incluso convertida en "la forma mas acabada del ejercicio del poder empresarial" (M.A. Souriac, 2002, págs. 53 y 57). Habida cuenta del peso del poder 
empresarial en las pequeñas y medianas empresas y de la debilidad de los negociadores sindicales, la negociación colectiva de empresa aislada del sistema negocial incrementa el unilateralismo empresarial en la negociación colectiva y puede no ser otra cosa, en ciertas ocasiones, que la renovación de las formas tradicionales del ejercicio del poder empresarial, el medio de legitimar las decisiones unilaterales empresariales de separación del convenio de sector (F. Debord y J.F. Paulin, 2006, p. 117). En todo caso, la negociación colectiva de empresa encauza una vía técnica de diferenciación de condiciones de trabajo, manteniendo una disciplina colectiva imprescindible para la organización del trabajo y el ejercicio de los poderes empresariales, que las viejas tesis individualistas, sostenidas sobre la autonomía de la voluntad individual, no fueron capaces de alcanzar.

De encuadrar el poder organizativo empresarial, de corregir y temperar su ejercicio, la negociación colectiva de empresa como instrumento de ese ejercicio pasa a formar parte de la concepción institucionalista de la empresa. ¿Han renovado las reformas legales de 2012 esa concepción de la empresa?

La acentuación de la temporalidad del convenio colectivo subraya también su función de gestión. Las modificaciones legislativas de 2012 no han buscado ya la estabilidad del convenio colectivo para asegurar la paz laboral, sino estimular su capacidad de adaptación insistiendo sobre su condición de instrumento temporal de regulación de las condiciones de trabajo. Las distintas técnicas reformadoras analizadas coadyuvan a logro de este objetivo: la revisión ante tempus de los convenios vigentes (art. 86.1 ET), la modificación e inaplicación parcial de convenios colectivos aplicables a la empresa a instancias del empresario (art. 82.3 ET), la negociación de convenios de empresa "en cualquier momento de la vigencia de convenios colectivos de ámbito superior" (art. 84.2, párrafo primero, ET), y la pérdida de vigencia de los convenios colectivos denunciados y vencidos tras el agotamiento de su eficacia ultraactiva (art. 86.3 ET).

Consecuencia de todo ello ha sido la debilitación del sujeto sindical sin medios jurídicos bastantes - la obligación legal de negociar es el único medio en el ámbito de la legislación ordinaria, con sus efectos y con sus limitaciones- para presionar efectivamente sobre los procesos de negociación del ajuste de las condiciones de trabajo en favor del empleo. Las reformas del marco legal de la negociación colectiva de 2012 han afianzado la operación de redistribución de poderes y responsabilidades desde las confederaciones y federaciones sindicales hacia sus representaciones de empresa $-\mathrm{y}$ hacia las representaciones unitarias, legalmente legitimadas para negociar convenios de empresa y para inaplicar la disciplina convencional del sector, negociada por los sindicatos- y desde las confederaciones y federaciones empresariales hacia los empresarios como titulares de sus organizaciones productivas, redistribución que no funciona simétricamente, ni tiene iguales consecuencias, como es obvio, en el lado sindical y en el empresarial. El "Informe de evaluación del impacto de la reforma laboral" de 2012 advirtió de que si los negociadores de los niveles sectoriales no aportaban la flexibilidad necesaria a la regulación de las condiciones de trabajo tomarían su sitio los negociadores de 
empresa. De nuevo surge aquí la fuerza transformadora de la negociación colectiva de empresa y sus consecuencias sobre el sistema de relaciones laborales e incluso sobre la función misma del Derecho del Trabajo.

El nuevo marco legal de la negociación colectiva pide, en consecuencia, un nuevo modelo de comportamiento de las organizaciones sindicales y asociaciones empresariales en el que ejerzan sus cometidos, a los que les llama la Constitución y la ley (art. 83 ET), de modo que pongan fin a la anómala estructura de la negociación colectiva española y ordenen aspectos nuevos, cruciales, del sistema negocial y del entero sistema de relaciones laborales (estructura de la negociación colectiva, funciones de los convenios colectivos de empresa, inaplicaciones, modificaciones y pérdida de ultraactividad de los convenios colectivos de eficacia general y sus efectos).

\section{Bibliografía}

Casas Baamonde, M. E. y Rodríguez-Piñero, M. (2012). Las reformas de la reforma laboral de 2012, Relaciones Laborales, Núm. 15-18, agosto-septiembre, pp. 1-65.

Casas Baamonde, M. E.; Rodríguez-Piñero, M. y Valdés Dal-ré, F. (2013). El agotamiento de la ultraactividad del convenio colectivo, Relaciones Laborales, Núm. 9, septiembre, pp. 1-13.

Cruz Villalón, J. (2013). Impacto de las reformas laborales sobre la negociación colectiva, en La aplicación de la Reforma Laboral, Relaciones Laborales, Núm. 12, diciembre, pp. 199- 214.

Debord, F. y Paulin, J. F. (2006). La singularisation conventionnelle de l'entreprise face à la branche, en J. M. Béraud y A. Jeammaud, Le singulier en droit du travail, Dalloz, Paris, pp. 117.

De la Villa Gil, L. E. (1997). El papel de la ley en el sistema de relaciones laborales, en Ley y pacto en el derecho del Trabajo. Homenaje a Rafael Martínez Emperador, Revista del Ministerio de Trabajo y Asuntos Sociales. Derecho del Trabajo, Núm. 3, pp. 79-92.

De la Villa Gil, L. E. (2012). El Derecho del Trabajo ¿ha muerto o vive todavia? Reflexiones sobre la reforma laboral de 2012, El Cronista del Estado Social y Democrático de Derecho, Iustel, pp. 9-14.

Escudero Rodríguez, R. (2012). El Real Decreto-ley 3/2012, de 10 de febrero: la envergadura de una reforma profundamente desequilibradora de la negociación colectiva, en R. Escudero Rodríguez (coord.), La negociación colectiva en las reformas de 2010, 2011 y 2012, Ed. Cinca, Madrid, pp. 11-56. 
Goerlich Peset, J. M. (2013). Régimen de la negociación colectiva e inaplicación del convenio colectivo en la reforma de 2012, Tirant lo Blanch, Valencia.

Olarte, S. (2013). La ultraactividad de los convenios colectivos antes y después del 8 de julio de 2013. Debate doctrinal y primeras interpretaciones judiciales, Relaciones Laborales, Núm. 12, diciembre, pp. 215-236.

Rodríguez-Piñero, M. y Bravo-Ferrer (1992). La negociación colectiva como derecho de libertad y como garantía institucional, Relaciones Laborales, Núm. 7, julio, pp. 1-8.

Rodriguez-Piñero y Bravo-Ferrer, M.; Valdés Dal-ré, F. y Casas Baamonde, M. E. (2013). La aplicación de la Reforma Laboral, Relaciones Laborales, Núm. 12, diciembre, pp. 1-32.

San Martín Mazzucconi, C. (2014). Ultraactividad de los convenios colectivos: estado de la cuestión en el ámbito judicial, Nueva Revista Española de Derecho del Trabajo, Núm. 161, pp. 223-236.

Souriac, M.A. (2002). Pouvoir et convention collective, en J. PELISSIER (dir.), Le pouvoir du chef d' entreprise, Dalloz, París, pp. 54-64.

Supiot, A. (1996). La loi devorée par la convention?, en Ph. Gérard, F. Ost y M. van de Kerchove (dirs.), Droit négocié, droit imposé?, Pub. des Facultés Universitaires Saint-Louis, Bruselas, 1996, pp. 631-642.

Valdés Dal-Ré, F. (2004). La eficacia jurídica de los convenios colectivos, Temas Laborales, Núm. 76, pp. 21-66.

Valdés Dal-Ré, F. (2009). El derecho constitucional a la negociación colectiva, en M.E. Casas Baamonde y M. Rodríguez-Piñero y Bravo-Ferrer, Comentarios a la Constitución Española, Fundación Wolters Kluwer España, Madrid, pp. 957 a 972.

Valdés Dal-Ré, F. (2012). (1). La negociación colectiva, entre tradición y renovación, Ed. Comares, Granada.

Valdés Dal-Ré, F. (2012). (2). La reforma de 2012 de la negociación colectiva: la irrazonable exacerbación de la función de gestión, Relaciones Laborales, Núm. 23-24, diciembre, pp. 221- 257.

Webb, S. y B. (1894). The History of Trade Unionism, ed. rev. 1920, Longmans, Londres. 